\title{
Salinity tolerance in plants. Quantitative approach to ion transport starting from halophytes and stepping to genetic and protein engineering for manipulating ion fluxes
}

\author{
Vadim Volkov* \\ Faculty of Life Sciences and Computing, London Metropolitan University, London, UK
}

OPEN ACCESS

Edited by: Bjoern Usadel,

RWTH Aachen University, Germany

Reviewed by:

Camila Caldana,

Brazilian Bioethanol Science and Technology Laboratory - Centro

Nacional de Pesquisa em Energia e Materiais/ABTLuS, Brazil Federico Valverde,

Instituto de Bioquímica Vegetal y Fotosíntesis, Spain

*Correspondence: Vadim Volkov

vadim.s.volkov@gmail.com

Specialty section:

This article was submitted to Plant Systems and Synthetic Biology, a section of the journal Frontiers in Plant Science

Received: 05 June 2015 Accepted: 01 October 2015 Published: 27 October 2015

Citation:

Volkov V (2015) Salinity tolerance in plants. Quantitative approach to ion transport starting from halophytes and stepping to genetic and protein engineering for manipulating ion fluxes. Front. Plant Sci. 6:873. doi: 10.3389/fpls.2015.00873
Ion transport is the fundamental factor determining salinity tolerance in plants. The Review starts from differences in ion transport between salt tolerant halophytes and salt-sensitive plants with an emphasis on transport of potassium and sodium via plasma membranes. The comparison provides introductory information for increasing salinity tolerance. Effects of salt stress on ion transport properties of membranes show huge opportunities for manipulating ion fluxes. Further steps require knowledge about mechanisms of ion transport and individual genes of ion transport proteins. Initially, the Review describes methods to measure ion fluxes, the independent set of techniques ensures robust and reliable basement for quantitative approach. The Review briefly summarizes current data concerning $\mathrm{Na}^{+}$and $\mathrm{K}^{+}$concentrations in cells, refers to primary thermodynamics of ion transport and gives special attention to individual ion channels and transporters. Simplified scheme of a plant cell with known transport systems at the plasma membrane and tonoplast helps to imagine the complexity of ion transport and allows choosing specific transporters for modulating ion transport. The complexity is enhanced by the influence of cell size and cell wall on ion transport. Special attention is given to ion transporters and to potassium and sodium transport by HKT, HAK, NHX, and SOS1 proteins. Comparison between non-selective cation channels and ion transporters reveals potential importance of ion transporters and the balance between the two pathways of ion transport. Further on the Review describes in detail several successful attempts to overexpress or knockout ion transporters for changing salinity tolerance. Future perspectives are questioned with more attention given to promising candidate ion channels and transporters for altered expression. Potential direction of increasing salinity tolerance by modifying ion channels and transporters using single point mutations is discussed and questioned. An alternative approach from synthetic biology is to create new regulation networks using novel transport proteins with desired properties for transforming agricultural crops. The approach had not been widely 
used earlier; it leads also to theoretical and pure scientific aspects of protein chemistry, structure-function relations of membrane proteins, systems biology and physiology of stress and ion homeostasis. Summarizing, several potential ways are aimed at required increase in salinity tolerance of plants of interest.

Keywords: salinity tolerance, halophyte, ion channel, ion transporter, ion fluxes, systems biology, synthetic biology, protein engineering

Salinity is among the most serious problems for modern agriculture with the estimated annual losses nowadays being over USD 12 billion (Pitman and Läuchli, 2002; Shabala, 2013). More than $20 \%$ of irrigated lands and up to $50 \%$ (Flowers, 1998) are affected by salinity; it essentially reduces the yield of agricultural crops since most of them are salt-sensitive glycophytes (Munns and Tester, 2008). The collapse of Sumer civilization about 4000 years ago was caused by improper agricultural techniques, which led to soil salinization and drop in the agricultural productivity in the area (Serrano, 1996; Pitman and Läuchli, 2002). However, progress in modern agriculture and science rather allowed to set problems and pose questions than to get clear answers. We still do not know how to deal with salinity and to grow plants under salinization.

Effects of salinity on living plants include osmotic stress, toxic effects of high salt, mostly sodium ions, and corresponding oxidative stress (Flowers, 2004; Munns and Tester, 2008; Shabala, 2013). Osmotic stress is proportional to concentration of external salt solution, usually with osmotic pressures over $1 \mathrm{MPa}$. Toxic effect of sodium ions results from their rise in cytoplasm of plant cells. Developing in plant cells oxidative stress adds to the negative effects of salinity on the whole plants.

Ion transport via cell membranes is the basic factor determining salinity tolerance. Ion fluxes control ion concentrations; finally the values and regulation of the fluxes are essential for salinity tolerance. The review starts from brief description of ion transport in halophytes. Then it provides basic details and features of ion transport aiming to understand what could be altered and the potential results of the changes. Further discussion is directed to specific transporters and to genetically modified and artificially designed transport proteins for modulating ion transport under conditions of salinization.

\section{ION TRANSPORT IN HALOPHYTES AND EFFECTS OF SALT STRESS ON MEMBRANE TRANSPORT IN GLYCOPHYTES}

Brilliant examples of salinity tolerance are represented by halophytes, which are able to grow at high concentrations of salt (Figure 1), under irrigation by seawater and even under several times higher salt concentrations than in seawater (over $2 \mathrm{M}$ of $\mathrm{NaCl}$ ) (Flowers et al., 1977; Flowers and Colmer, 2008). Halophytes are usually considered like sodium tolerant plants. Indeed, $\mathrm{NaCl}$ is the main source of salinity in most areas, though chloride, sulfate, calcium, magnesium, and the other ions are involved constituting sometimes the main salt for soil and water salinization (Flowers et al., 1977). "Domestication" of halophytes is one more way to use salt-affected and salinized territories.

Halophytes is an undisputable example and proof that salinity tolerance in plants is achievable. The main questions are:

- what are the salinity tolerance traits in halophytes;

- how to bring the relevant trait or multiple traits to agricultural plants;

- to which extent the transfer could be realized without essentially influencing the growth rate, agricultural productivity and quality of grain, fruits, edible parts, flowers or the other economically important elements/features/traits of agricultural plants.

The simplest idea under salinity is to decrease sodium net influx and increase potassium net uptake via plasma membrane of epidermal root cells to alter mineral nutrition. Surprisingly, in most cases the pure straightforward and strict approach is not realized neither in halophytes, nor in glycophytes (Flowers, 2004; Maathuis et al., 2014). Halophytes imply several strategies to cope with high concentrations of salts including (1) sodium exclusion from roots, (2) accumulation of high sodium in shoots, (3) shedding specialized leaves, (4) localizing salts in vacuoles, (5) excreting salts via salt glands etc. The role and contribution of each strategy depend on the habitat and type of a

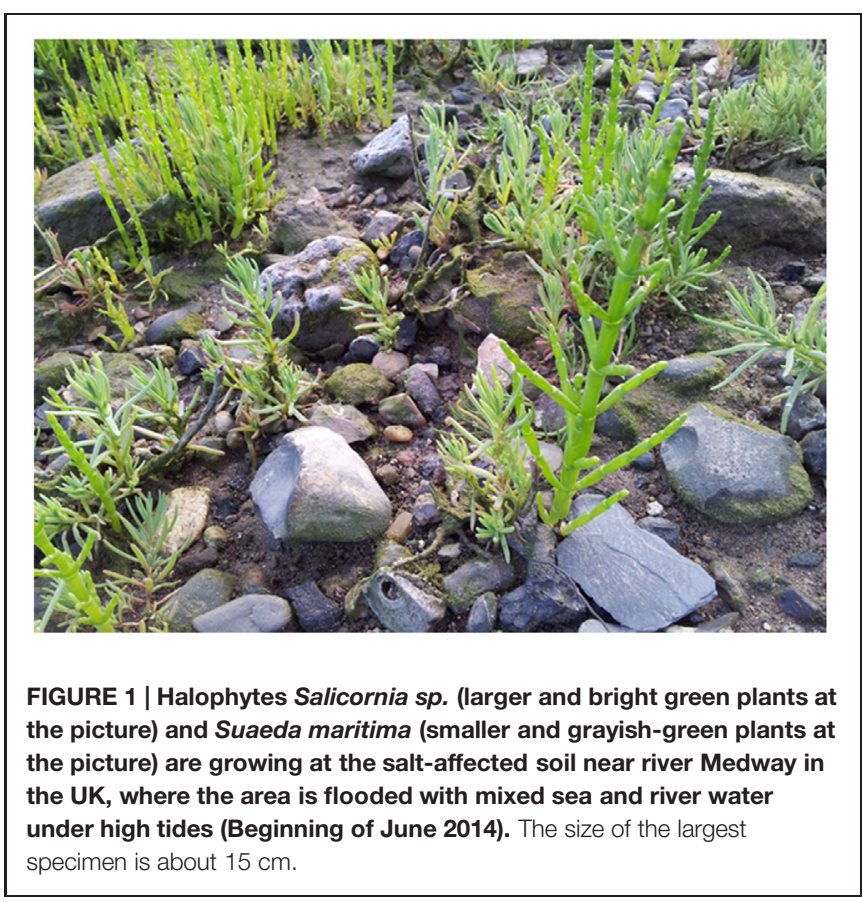


halophyte plant (Flowers et al., 1977; Breckle, 2002; Lüttge, 2002; Flowers and Colmer, 2008; Munns and Tester, 2008; Shabala, 2013). So far the known transport systems in halophytes are basically the same like in glycophytes due to common ancestry and evolution (Flowers et al., 2010): the trait of salt tolerance emerged independently over 70 times in different groups of grasses (Bennett et al., 2013). The knowledge facilitates potential transfer of salinity tolerance traits to agriculturally important plants.

It is important to consider living cell as a complex system. There are networks of signaling events and metabolic reactions. Under salinity the increase in cytoplasmic $\mathrm{Na}^{+}$and reduction of $\mathrm{K}^{+}$result in changes of membrane potential, osmotic pressure, turgor pressure, calcium signaling, reactive oxygen species signaling, transcriptional regulation, alteration of gene expression, modification of protein expression pattern and spectra of siRNAs, signaling molecules, phytohormones and metabolites. The set of parameters including ion fluxes characterizes cell in a definite physiological state. Transition from one physiological state to the other one could be described by a trajectory in a multidimensional space, while the stable physiological states are considered as dynamic attractors. The volume and shape of the attractor in multidimensional space could be registered using means of "omics" that is RNA expression microarrays, proteomics, ionomics, metabolomics etc. (Figure 2). Properties of the attractors are slowly studied and understood for biological systems (Spiller et al., 2010; Breeze et al., 2011), though the idea is initially well developed in physics, especially in plasma physics for non-equilibrium thermodynamic systems (Akhromeeva et al., 1989, 1992). Obviously and intuitively the biological systems with tens of thousands of participating expressed genes are more complex than physical systems. Salt treatment up- and down-regulates tens and hundreds of genes including transcription factors, genes of transporters and regulatory proteins (e.g., Taji et al., 2004; Volkov et al., 2004; Liu et al., 2013; Takahashi et al., 2015) when

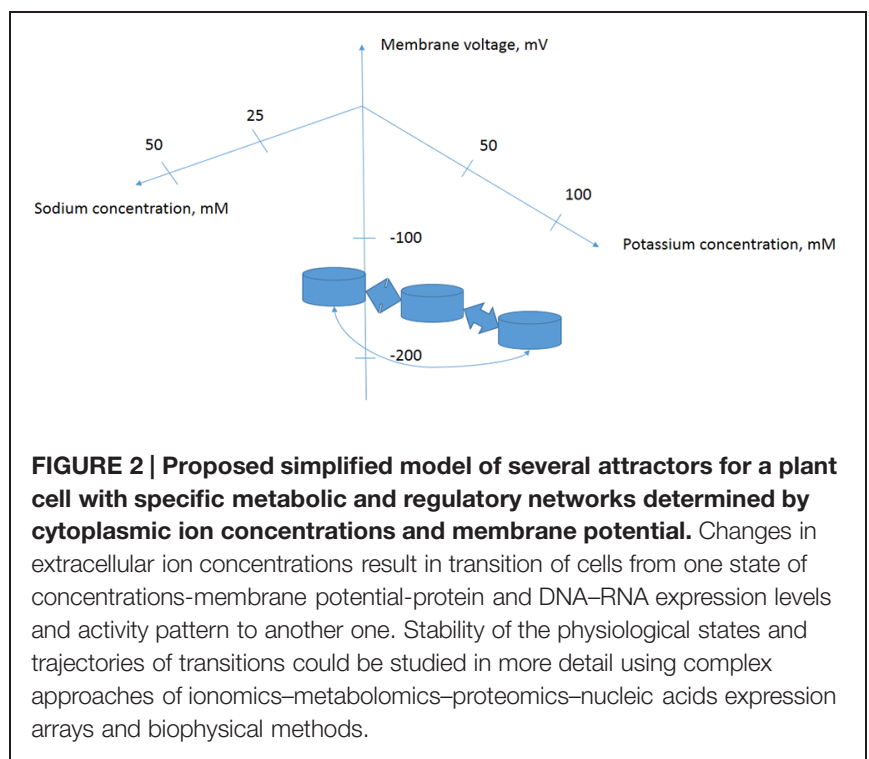

the cells are moving to a new distinct physiological state of gene expression, metabolic control and ion transport.

Comparison of ion fluxes via membranes between halophytes and glycophytes often demonstrates lower sodium uptake for halophytes (reviewed in: Flowers and Colmer, 2008). However, an evident problem in comparison is the high variability in ion transport between plant species because of growth rate, tissue-specific variability and the other physiological factors. It is reasonable to consider similar plants and achieve comparable values. Recent results on ion fluxes in glycophyte Arabidopsis thaliana and similar from the point of genome and morphology halophyte Thellungiella halophila demonstrated lower $\mathrm{Na}^{+}$fluxes and higher $\mathrm{K}^{+} / \mathrm{Na}^{+}$selectivity of ion currents in the roots and root protoplasts of the halophyte under salt treatment (Figures 3 and 4, and in: Volkov et al., 2004; Volkov and Amtmann, 2006; Wang, 2006; Wang et al., 2006; Amtmann, 2009; resembling results for roots of the two plants: Alemán et al., 2009). Lower $\mathrm{Na}^{+}$accumulation and higher $\mathrm{K}^{+} / \mathrm{Na}^{+}$ratio under salt treatment were also found in roots of leguminous halophyte Melilotus indicus compared to similar herbaceous glycophyte Medicago intretexta (Zahran et al., 2007).

Other strategies may be involved depending on the level of salinity tolerance, plant morphology, habitat and the other environmental factors and evolutionary history. For example, salt tolerant Plantago maritima had similar sodium uptake rates by roots compared to salt-sensitive P. media (Erdei and Kuiper, 1979; de Boer, 1985); the salt-tolerance in the pair is rather associated with xylem transport and sodium accumulation in vacuoles of leaf cells.

Vacuolar membranes of several halophytes were also a subject of special investigation. Electrophysiological patch clamp study of vacuoles from leaves of Suaeda maritima did not find any unusual features to support the high salt tolerance of the halophyte (Maathuis et al., 1992). Patch clamp experiments to compare vacuoles from roots of $P$. maritima and $P$. media also

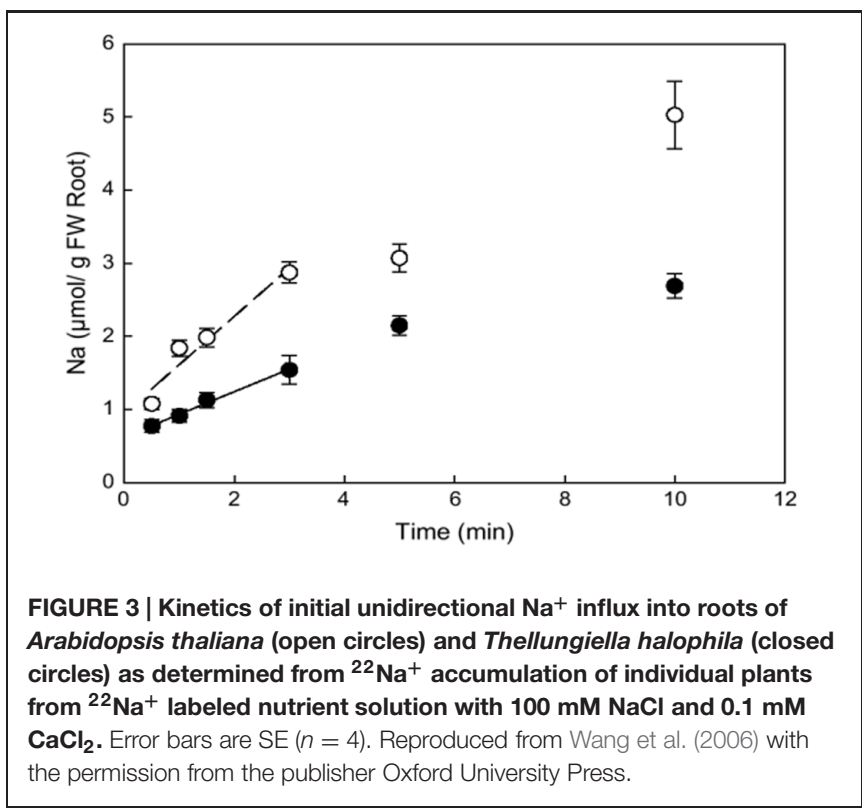




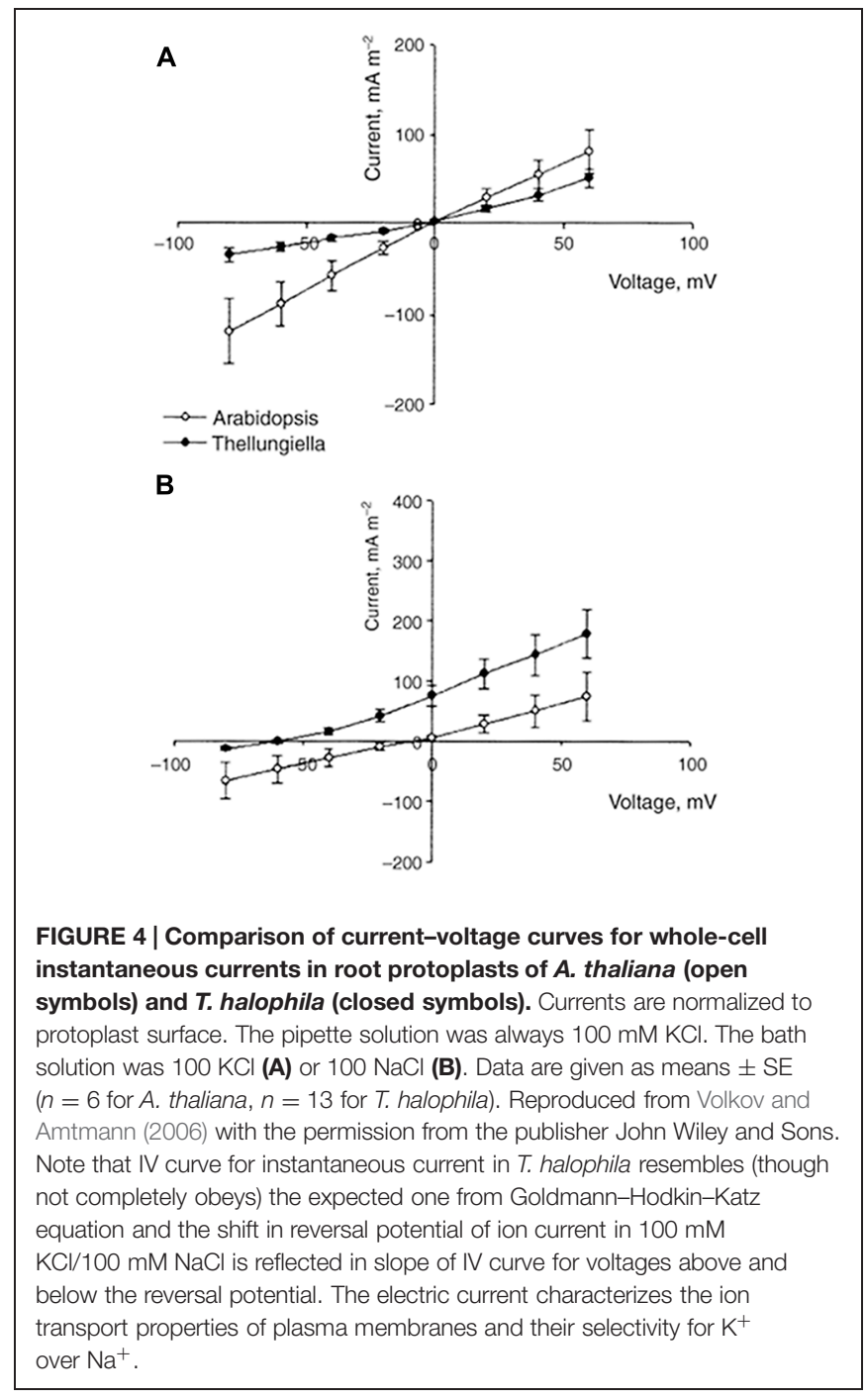

did not reveal striking differences apart from an extra smaller ion channel conductance in the tonoplast of the halophyte; salt stress essentially reduced the open probability of larger non-selective between $\mathrm{K}^{+}$and $\mathrm{Na}^{+}$ion channel conductance in both species but did not change the properties of the conductance (Maathuis and Prins, 1990). However, comparison of tonoplast from suspension culture cells of halophytic sugar beet with glycophytic tomato revealed rectification properties of ion channels in vacuolar membrane of the halophyte (Pantoja et al., 1989). At positive voltages in outside-out configuration (corresponding to ion currents out of vacuole) the ion-channellike conductance dropped 6.5 times presumably preventing the transport of ions from vacuole to cytoplasm; the conductance was not selective for $\mathrm{K}^{+}$over $\mathrm{Na}^{+}$in both species (Pantoja et al., 1989).

Complexity of ion transport within the whole plant under salinity is confirmed also in experiments with glycophytes. Ion transport could be essentially influenced by salt stress in a cell-specific manner. The information is required to consider the whole plant responses to salinity and to alter them in a desired direction. An example of changes in membrane electric conductance after salt stress in several types of cells from barley leaves is given in Figure 5.

\section{BASIC ASSUMPTIONS FOR REGULATING ION TRANSPORT IN PLANT CELLS}

Before pondering ways to modulate ion transport it is helpful to describe techniques to measure ion fluxes and then introduce basic important parameters, which could be influenced and manipulated to alter ion fluxes and intracellular ion concentrations. The knowledge is also required to explain, understand and predict the results with overexpression/knockout of individual transporters and ion pumps (see below).

\section{Comparison between Different Methods for Measuring lon Fluxes}

Total activity of proton pumps, ion channels, transporters and potential "leak" pathways of ion transport (see below) is reflected in changing and regulated ion fluxes. The coinciding values of ion fluxes measured by several independent techniques are needed to provide reliable and robust basis for the further conclusions. Direct and indirect methods include (1) estimates based on kinetic measurements of ion concentrations (both in plants and in nutrient solution), (2) electrophysiological methods, (3) technique of measuring ion fluxes using vibrating ion-selective electrodes [microelectrode ion flux estimate/measurements (MIFE)], (4) measurements of unidirectional ion fluxes (e.g., radioactive isotope ${ }^{22} \mathrm{Na}^{+}$for sodium, while $\mathrm{Rb}^{+}$is often used to imitate $\mathrm{K}^{+}$fluxes) and (5) several other methods including ionselective fluorescent and non-fluorescent indicators, potentially NMR spectroscopy, ion-conductance scanning microscopy etc. (Table 1).

Estimates from ion concentrations are the sum of influx and efflux of ions from plant cells. The measurements finally provide the important physiological information about averaged net changes and fluxes. However, the existing concentrations are often already high, therefore it takes at least hours and sometimes days to determine kinetic changes of ion concentrations and obtain kinetic curves, usually without detailed peculiarities and high temporal resolution of minutes. For example, after $25 \mathrm{~h}$ of $100 \mathrm{mM} \mathrm{NaCl}$ treatment sodium contents in roots of glycophyte A. thaliana rose from 0.2 to $2 \%$ of dry weight (DW) of the roots $\left(0.087-0.87\right.$ mmole $\mathrm{Na}^{+}$per $\mathrm{g}$ of $\left.\mathrm{DW}\right)$, while in halophyte T. halophila sodium in roots increased from 0.15 to $1.2 \%$ (0.065-0.52 mmole $\mathrm{Na}^{+}$per $\mathrm{g}$ of DW) (Volkov et al., 2004). Fast initial rates of net $\mathrm{Na}^{+}$uptake by roots during the first $6 \mathrm{~h}$ were $0.064 \mu \mathrm{mole} /\left(\mathrm{g}\right.$ root $\left.\mathrm{DW}^{*} \mathrm{~min}\right)$ in Thellungiella and $0.048 \mu \mathrm{mole} /\left(\mathrm{g}\right.$ root $\left.\mathrm{DW}^{*} \mathrm{~min}\right)$ in Arabidopsis. After $24 \mathrm{~h}$ of salt treatment, the rates dropped to $0.0004 \mathrm{nmole} /(\mathrm{g}$ root $\mathrm{DW}^{*} \mathrm{~min}$ ) in Thellungiella and $0.003 \mathrm{nmole} /\left(\mathrm{g}\right.$ root $\left.\mathrm{DW}^{*} \mathrm{~min}\right)$ in Arabidopsis (Wang, 2006).

To elucidate detailed mechanisms of ion transport it is essential to add the other methods. One more requirement 


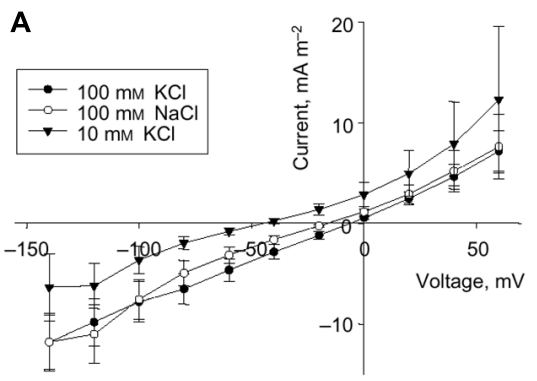

B

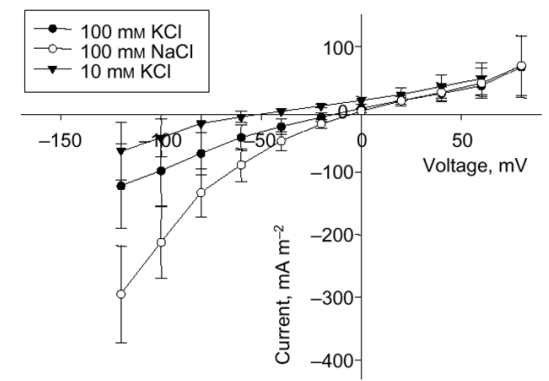

C

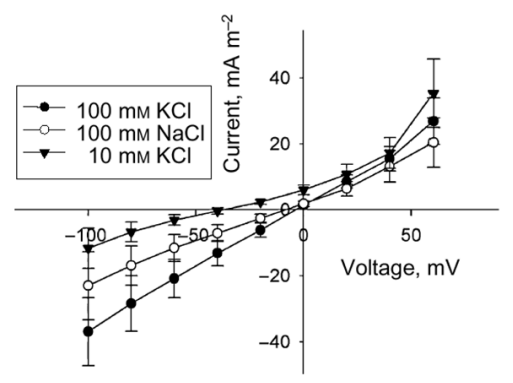

D

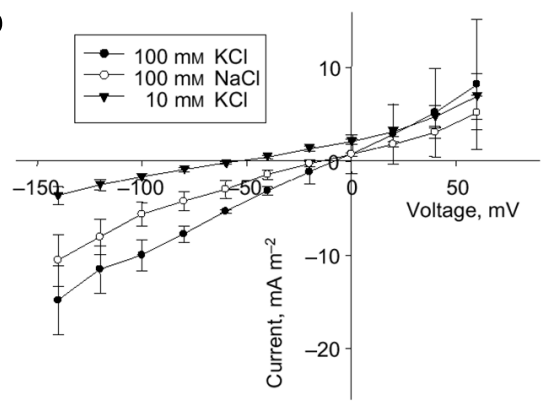

E

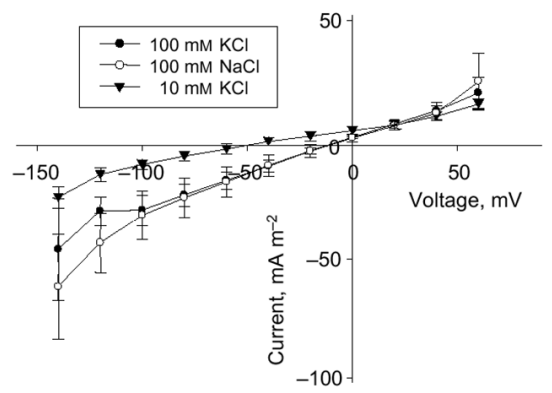

$\mathbf{F}$

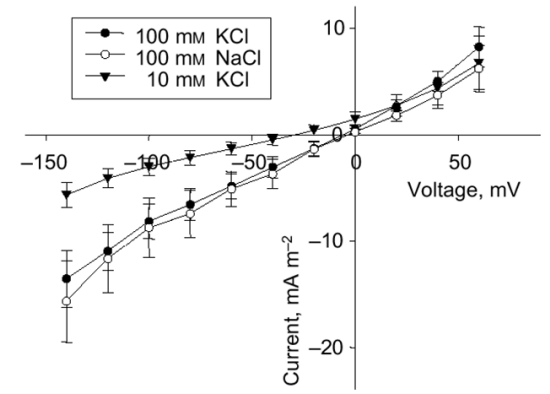

FIGURE 5 | Effect of salt stress on instantaneous current in protoplasts from the elongation zone and emerged blade portion of the developing leaf 3 of barley (Hordeum vulgare L.) (A-F). Averaged current-voltage (I-V) relationship in protoplasts from mesophyll $(\mathbf{A}, \mathbf{D})$ and epidermis $(\mathbf{B}, \mathbf{E})$ of the emerged blade, and from protoplasts of the elongation zone (C,F). Control (A-C) and salt treatment (D-F), $n=5-8$ for control protoplasts and $n=3-6$ for protoplasts for salt treatment; error bars are standard errors. Concentrations of $\mathrm{KCl}$ and $\mathrm{NaCl}$ in the bath are indicated. The pipette solution was always $100 \mathrm{mM} \mathrm{KCl}$. Plants had been exposed to $100 \mathrm{mM} \mathrm{NaCl}$ for 3 days prior to protoplast isolation. Reproduced from Volkov et al. (2009), composed from Figures 1, 2, 4 and 5 with the permission from the publisher John Wiley and Sons.

is to compare ion fluxes measured by different techniques: changes of ion concentrations are expressed in moles/g of fresh or dry weight (FW or DW), while electrophysiological and MIFE measurements are normalized per a unit of surface area, $\mathrm{A} / \mathrm{m}^{2}$ and moles $/\left(\mathrm{m}^{2 *} \mathrm{~s}\right)$, correspondingly. Rough estimate for conversion is that DW is about $10-15 \%$ of $\mathrm{FW}$; for recalculation per surface area the size of roots or protoplasts is required. Estimates relating potassium flux in epidermal cells to ion electric currents were done for rye roots (White and Lemtiri-Chlieh, 1995). The net $\mathrm{K}^{+}$flux was estimated 1.0-1.9 $\mu \mathrm{mole} /(\mathrm{g}$ root $\mathrm{WF}^{*} \mathrm{~h}$ ) and unidirectional $\mathrm{K}^{+}$flux was about $7 \mu \mathrm{mole} /(\mathrm{g}$ root
$\mathrm{WF}^{*} \mathrm{~h}$ ) from mineral solution with $0.6 \mathrm{mM} \mathrm{K}^{+}$(White et al., 1991). Epidermal cells with diameter $26 \mu \mathrm{m}$ were considered $8.3 \%$ of root volume; then the net fluxes in $\mu \mathrm{mole} /(\mathrm{g}$ root $\mathrm{WF}^{*} \mathrm{~h}$ ) corresponded to $0.11-0.21 \mathrm{pmole} /\left(\mathrm{cell}{ }^{*}\right.$ hour) or 3.1$5.9 \mathrm{pA} / \mathrm{cell}$. Unidirectional flux of $7 \mu \mathrm{mole} /\left(\mathrm{g}\right.$ root $\left.\mathrm{WF}^{*} \mathrm{~h}\right)$ corresponded to $0.77 \mathrm{pmole} /(\mathrm{cell}$ *hour) or $21.7 \mathrm{pA} / \mathrm{cell}$ (White and Lemtiri-Chlieh, 1995). Converting per surface area of the whole protoplasts, the fluxes of 0.11-0.21 pmole/(cell ${ }^{*}$ hour) correspond to $14-27 \mathrm{nmole} /\left(\mathrm{m}^{2 *} \mathrm{~s}\right)$ and $0.77 \mathrm{pmole} /($ cell*hour) $\approx 100 \mathrm{nmole} /\left(\mathrm{m}^{2 *} \mathrm{~s}\right)$, the values reasonably confirmed by the other methods (see below). Conversion of the flux in pmoles to 
TABLE 1 | Comparative summary for methods to measure ion fluxes in plants and their tissues and cells.

\begin{tabular}{|c|c|c|c|}
\hline $\begin{array}{l}\text { Method or group of } \\
\text { methods }\end{array}$ & Principle of the method & $\begin{array}{l}\text { Spatial and temporal resolution, } \\
\text { advantages }\end{array}$ & Disadvantages \\
\hline $\begin{array}{l}\text { Kinetic measurements } \\
\text { of ion concentrations }\end{array}$ & $\begin{array}{l}\text { Ion concentrations in plant tissues or in } \\
\text { nutrient solution are measured in time, the } \\
\text { concentration differences along the time } \\
\text { points are plotted against time. }\end{array}$ & $\begin{array}{l}\text { Resolution is at the level of whole plant or } \\
\text { plant tissues, usually tens of minutes and } \\
\text { hours are needed to register changes. Simple } \\
\text { methods without a need of special equipment, } \\
\text { convenient for most ions. }\end{array}$ & $\begin{array}{l}\text { Measures net fluxes, not separate influx } \\
\text { and flux outside of plant tissues. Low } \\
\text { level of resolution. }\end{array}$ \\
\hline $\begin{array}{l}\text { MIFE: microelectrode } \\
\text { ion flux estimate/ } \\
\text { measurements }\end{array}$ & $\begin{array}{l}\text { Tiny ion-selective microelectrode with tip } \\
\text { around a } \mu \text { meter vibrates within seconds in } \\
\text { the vicinity of a cell or plant tissue and } \\
\text { measures ion concentrations. Changing in } \\
\text { time difference in concentrations is } \\
\text { recalculated to ion fluxes. }\end{array}$ & $\begin{array}{l}\text { Resolution at the level of individual cells within } \\
\text { seconds, measurements may last for hours. }\end{array}$ & $\begin{array}{l}\text { Requires special equipment. } \\
\text { lon-selective electrodes often interfere } \\
\text { with organic compounds. Reliable } \\
\text { ion-selective resins available for a few } \\
\text { major ions only. }\end{array}$ \\
\hline $\begin{array}{l}\text { Measurements of } \\
\text { unidirectional ion fluxes }\end{array}$ & $\begin{array}{l}\text { Plant tissues or organs are loaded with } \\
\text { radioactive ions or rare ions to imitate ions of } \\
\text { interest. Unidirectional usually outward ion } \\
\text { fluxes of the isotope or rare ion are measured } \\
\text { then as changes in concentrations against } \\
\text { time. }\end{array}$ & $\begin{array}{l}\text { Spatial resolution at the level of whole plant or } \\
\text { plant tissues, recordings from minutes lasting } \\
\text { to hours are needed to register changes. }\end{array}$ & $\begin{array}{l}\text { Requires radioactive isotopes and often } \\
\text { complicated calculations with several } \\
\text { proposed pools of ions. }\end{array}$ \\
\hline $\begin{array}{l}\text { Electrophysiological } \\
\text { methods }\end{array}$ & $\begin{array}{l}\text { Isolated cell membrane, piece of membrane } \\
\text { or single cell within a plant preparation are } \\
\text { subjected to set of physiological voltages and } \\
\text { ion current is registered in the form of electric } \\
\text { current. }\end{array}$ & $\begin{array}{l}\text { Spatial resolution of single molecules or single } \\
\text { cells. Temporal resolution from } \mu \text { seconds to } \\
\text { minutes. High accuracy and possibility to find } \\
\text { out specific molecules for transport of definite } \\
\text { ions. }\end{array}$ & $\begin{array}{l}\text { Indirect measurements, measure total } \\
\text { electric current carried out by several } \\
\text { ion species. }\end{array}$ \\
\hline Fluorescent indicators & Fluorescent ion selective indicators & $\begin{array}{l}\text { Resolution at the level of individual cells within } \\
\text { tens of seconds to minutes, recordings over } \\
\text { tens of minutes to hours. }\end{array}$ & $\begin{array}{l}\text { Require specific protocols for loading, } \\
\text { intrinsic autofluorescence and } \\
\text { non-specific adsorption of fluorescent } \\
\text { indicators could be drawbacks. }\end{array}$ \\
\hline
\end{tabular}

The distinction between the methods is partially arbitrary.

number of ions per a cell gives 0.77 pmole/(cell*hour) $\approx 1.3 * 10^{8}$ ions/(cell*second) (see below).

Electrophysiological techniques of two-electrode voltage clamp or patch clamp measure ion currents across membrane of plant cells (protoplasts for patch clamp) under determined applied voltage via the membrane and provide current-voltage curves with resolution up to $\mathrm{pA}$ and $\mu$ seconds (Figures $\mathbf{4}$ and 5). For the example of patch clamp study with root protoplasts of Arabidopsis and Thellungiella, the inward $\mathrm{K}^{+}$fluxes in external $100 \mathrm{mM} \mathrm{KCl}$ at $-80 \mathrm{mV}$ were $120 \mathrm{~mA} / \mathrm{m}^{2}=120 \mathrm{fA} / \mu \mathrm{m}^{2} \approx 1.2$ $10^{-18} \mathrm{~mole} /\left(\mu \mathrm{m}^{2 *} \mathrm{~s}\right)=1.2 \mu \mathrm{mole} /\left(\mathrm{m}^{2 *} \mathrm{~s}\right)$ for Arabidopsis and $30 \mathrm{~mA} / \mathrm{m}^{2} \approx 300 \mathrm{nmole} /\left(\mathrm{m}^{2 *} \mathrm{~s}\right)$ for Thellungiella, correspondingly. Inward $\mathrm{Na}^{+}$fluxes under the same conditions, but in $100 \mathrm{mM} \mathrm{NaCl}$ in the external medium are $70 \mathrm{~mA} / \mathrm{m}^{2}$ $\approx 700 \mathrm{nmole} /\left(\mathrm{m}^{2 *} \mathrm{~s}\right)$ for Arabidopsis and $15 \mathrm{~mA} / \mathrm{m}^{2} \approx$ $150 \mathrm{nmole} /\left(\mathrm{m}^{2 *} \mathrm{~s}\right)$ for Thellungiella (Volkov and Amtmann, 2006).

Comparisons of electric currents and ion fluxes were performed in a series of simultaneous measurements using patch clamp and MIFE for wheat root protoplasts, when MIFE measured $\mathrm{H}^{+}$fluxes (Tyerman et al., 2001). Proton fluxes in the experiments basically correlated to electric currents, though with large variation between protoplasts (Tyerman et al., 2001). Further on MIFE proved the lack of "dark" electroneutral fluxes for $\mathrm{K}^{+}$transport in the wheat root protoplasts (the situation was different for $\mathrm{Ca}^{2+}$, large $\mathrm{Ca}^{2+}$ fluxes were not electrogenic): $\mathrm{K}^{+}$ion currents via outward and inward potassium channels nearly exactly corresponded to the $\mathrm{K}^{+}$ion fluxes measured by ion selective electrodes of MIFE (Tyerman et al., 2001; Gilliham et al., 2006). Some deviations from 1:1 ratio and variation between protoplasts were explained by uneven distribution of ion channels (Gilliham et al., 2006). Potentially atomic force microscopy or ion-conductance scanning microscope with further ion channel recordings (e.g., Hansma et al., 1989; Korchev et al., 1997; Lab et al., 2013 for ion-conductance scanning microscope) could be useful to explore the distribution of lipid rafts and clusters of ion channels at nanometre resolution.

Values of ion fluxes measured by patch clamp in protoplasts are usually higher than fluxes measured by MIFE for intact roots (e.g., Shabala and Lew, 2002; Chen et al., 2013), but coincide within orders of magnitude and essentially depend on composition of ambient medium, concentration of ions, membrane potential of cells and on multiple physiological factors (e.g., Ivashikina et al., 2001; Shabala et al., 2009). Experiments with MIFE are non-invasive and simpler; therefore provide huge opportunities with temporal resolution of seconds and spatial resolution within less than tens of microns for exploring physiological factors and conditions, which influence ion fluxes to and out of cells (Newman et al., 1987; Newman, 2001; Shabala, 2006; Sun et al., 2009; Shabala and Bose, 2012). Ion fluxes of $\mathrm{K}^{+}, \mathrm{Na}^{+}$, and other ions in the vicinity of roots were measured by MIFE and compared for different salt-tolerant and saltsensitive cultivars and agricultural species (Chen et al., 2005; Cuin et al., 2008, 2012), along root zones of several plants (Garnett et al., 2001; Chen et al., 2005; Pang et al., 2006), for mutants in specific ion channels or transporters (e.g., Shabala et al., 
2005; Demidchik et al., 2010), under treatment by physiologically active compounds (Cuin and Shabala, 2007a; Shabala et al., 2009; Pandolfi et al., 2010; Demidchik et al., 2011; Ordoñez et al., 2014), after generation of reactive oxygen species and salt stress (Cuin and Shabala, 2007b; Demidchik et al., 2010) and for numerous other conditions. MIFE is also a good method for studying ion transport in cell biology (Lew et al., 2006; Valencia-Cruz et al., 2009; Demidchik et al., 2010). The results provided huge volume of information about characteristics, kinetics and physiological features of ion fluxes under salt stress, helped to develop fast tests for salinity tolerance (Chen et al., 2005; Cuin et al., 2008). The results are described in hundreds of publications and several reviews (e.g., Newman, 2001; Shabala, 2006; Sun et al., 2009; Shabala and Bose, 2012), so are not covered here in more detail. Among the limitations of MIFE is the selectivity of ion-selective electrodes, which is influenced by interfering ions (e.g., Knowles and Shabala, 2004) and sometimes affected by physiologically active compounds and proteins in the medium for measurements after interaction with the material of ion-selective electrodes (e.g., Chen et al., 2005), hence demanding more control checks.

Unidirectional fluxes of ${ }^{22} \mathrm{Na}^{+}$for sodium and ${ }^{42} \mathrm{~K}^{+}$or $\mathrm{Rb}^{+}(\mathrm{a}$ tracer for $\mathrm{K}^{+}$) provide fast kinetics of ion transport within tens of seconds as determined by the speed of sampling and changes in concentrations at the background of initial level without ${ }^{22} \mathrm{Na}^{+}$ and ${ }^{42} \mathrm{~K}^{+} / \mathrm{Rb}^{+}$(e.g., Figure 5 for ${ }^{22} \mathrm{Na}^{+}$fluxes). The method is used widely and had already provided essential advances in plant ion transport (e.g., MacRobbie and Dainty, 1958; Rains and Epstein, 1965; Epstein, 1966). The outward fluxes could be measured after loading plants with ${ }^{22} \mathrm{Na}^{+}$or ${ }^{42} \mathrm{~K}^{+} / \mathrm{Rb}^{+}$and transferring then to different chemical solutions without the ions (e.g., Wang, 2006; Wang et al., 2006 for ${ }^{22} \mathrm{Na}^{+}$for roots of Arabidopsis and Thellungiella). Details and the methodical procedures are well described with different modifications to get more information about compartmentation of the absorbed ions and to exclude potential sources of errors (Cheeseman, 1986 for analysis of compartmentation based on efflux kinetics; Britto et al., 2006; Wang, 2006 for ${ }^{42} \mathrm{~K}^{+}$in application for the tracer efflux by barley roots; Britto and Kronzucker, 2013 for comprehensive practical description of experimental procedures to measure potassium fluxes). The values of measured fluxes differ significantly, sometimes over 100 times depending on plant species, physiological conditions and ion concentrations (e.g., summarized for $\mathrm{Na}^{+}$fluxes in: Kronzucker and Britto, 2011).

Analysis of unidirectional fluxes is often complemented by the other methods to obtain better understanding of the processes. An interesting comparison for influx of $\mathrm{K}^{+}$ $\left({ }^{86} \mathrm{Rb}^{+}\right)$from $0.1 \mathrm{mM} \mathrm{K} \mathrm{SO}_{4}$ solution and net $\mathrm{K}^{+}$influx measured by external $\mathrm{K}^{+}$microelectrodes (prototype of MIFE) gave nearly the same values of fluxes: $2.6 \mu \mathrm{mole} /\left(\mathrm{g} \mathrm{FW}{ }^{*} \mathrm{~h}\right)$ and $2.5 \mu \mathrm{mole} /\left(\mathrm{g} \mathrm{FW} \mathrm{FW}^{*} \mathrm{~h}\right.$ ), correspondingly (Newman et al., 1987). Measurements of unidirectional ${ }^{24} \mathrm{Na}^{+},{ }^{42} \mathrm{~K}^{+}$fluxes in barley together with membrane potential measurements and pharmacological profiling of the fluxes allowed to study high affinity transport of sodium from low $\mu \mathrm{M}-50 \mathrm{mM}$ solutions and provided predictions about possible mechanisms for the transport (Schulze et al., 2012).
Among methods to determine ion fluxes is the use of ionselective fluorescent indicators for estimating cytoplasmic and vacuolar concentrations of $\mathrm{Na}^{+}$and $\mathrm{K}^{+}$and kinetics of their changes (e.g., mostly for protoplasts: Lindberg, 1995; Halperin and Lynch, 2003; D’Onofrio et al., 2005; Kader and Lindberg, 2005), measurements by intracellular ion-selective electrodes (e.g., Carden et al., 2003 and references there), ${ }^{23} \mathrm{Na}-\mathrm{NMR}$ spectroscopy (e.g., Bental et al., 1988) and several others; the methods are not discussed in detail here.

\section{Ion Concentrations in Cells}

Ion concentrations are the reflection of net ion fluxes via plasma membrane. Certain range of ion concentrations, especially of $\mathrm{K}^{+}, \mathrm{Na}^{+}$, and $\mathrm{Ca}^{2+}$, is vital for cell physiology and function of proteins. Typical potassium concentrations in cytoplasm of plant cells were measured independently by several methods (including ion-selective electrodes, fluorescent dyes and X-ray microanalysis) and range around 60-140 mM (Pitman et al., 1981; Hajibagheri et al., 1988; Hajibagheri and Flowers, 1989; Walker et al., 1995, 1998; Korolev et al., 2000; Cuin et al., 2003; Halperin and Lynch, 2003; Shabala et al., 2006; Hammou et al., 2014), though concentrations above $200 \mathrm{mM}$ were estimated by efflux analysis (reviewed in Britto and Kronzucker, 2008) and as low as $12 \mathrm{mM}$ and even lower $\mathrm{K}^{+}$concentrations were measured by ion-selective electrodes in root cells of potassium-deprived Arabidopsis plants (Armengaud et al., 2009). Higher potassium concentrations of 200-350 mM measured in cell sap by X-ray microanalysis or capillary electrophoresis are rather attributed to vacuolar compartment under sufficient potassium supply (Malone et al., 1991; Fricke et al., 1994; Bazzanella et al., 1998; Volkov et al., 2004). It is worth mentioning that in animal cells potassium seems to be among regulators of apoptotic enzymes activating them at $\mathrm{K}^{+}$concentrations below $50 \mathrm{mM}$ (Hughes and Cidlowski, 1999).

Sodium cytoplasmic concentrations of plant cells are usually low reaching about 20-50 mM after several days of $\mathrm{NaCl}$ treatment (Carden et al., 2001, 2003; Halperin and Lynch, 2003). Higher sodium concentrations had also been measured depending on duration of salt stress, external sodium, concentration of the other ions and on plant species: cytoplasmic sodium concentrations over $200 \mathrm{mM}$ were reported in salttolerant halophytes (Hajibagheri and Flowers, 1989; Halperin and Lynch, 2003; Flowers and Colmer, 2008; Kronzucker and Britto, 2011).

An interesting example is halotolerant alga Dunaliella salina, which is a good unicellular eukaryotic model for studying salinity tolerance within the range of $0.05-5.5 \mathrm{M} \mathrm{NaCl}$ (e.g., Katz and Avron, 1985). Cytoplasmic sodium concentrations about $90 \mathrm{mM}(88 \pm 28 \mathrm{mM})$ were reported in the alga using ${ }^{23} \mathrm{Na}$ NMR spectroscopy (Bental et al., 1988). $\mathrm{Na}^{+}$concentrations were nearly the same (within the error of a few measurements) in the algal cells adapted to a wide range of external $\mathrm{Na}^{+}$, from 0.1 to $4 \mathrm{M}$ (Bental et al., 1988). Similar or even lower sodium concentrations below $100 \mathrm{mM}$ were measured by the other methods for the alga under $0.5-4 \mathrm{M}$ or $1-4 \mathrm{M}$ sodium treatment (Katz and Avron, 1985; Pick et al., 1986). The small alga $D$. salina has length about $10-11 \mu \mathrm{m}$, width of $6 \mu \mathrm{m}$ and 
volume around $200 \mathrm{fL}$ (Masi and Melis, 1997) or even smaller dimensions with volume around 90-100 fL then (Katz and Avron, 1985). It probably possesses specific transport system to exclude $\mathrm{Na}^{+}$, similar to $\mathrm{Na}^{+}$-ATPase expected to function in the plasma membrane of the marine unicellular alga Platymonas viridis (Balnokin and Popova, 1994), alga D. maritima (Popova et al., 2005) and several other marine algae (reviewed in: Balnokin, 1993; Gimmler, 2000).

High sodium concentrations over $100 \mathrm{mM}$ often have inhibiting effect on protein synthesis at least in salt-sensitive glycophytes (Hall and Flowers, 1973; Wyn Jones and Pollard, 1983; Flowers and Dalmond, 1992). Sodium is also (1) competing with potassium for allosteric sites of enzymes and (2) interacting with ion channels (for example, sodium ions change the gating of potassium outward rectifying currents in root protoplasts of halophyte plant Thellungiella, which are most likely carried by Shaker type potassium channels: Volkov and Amtmann, 2006). Moreover at the cellular level salt stress induces apoptosis (Katsuhara and Kawasaki, 1996; Huh et al., 2002; shortly reviewed in Shabala, 2009; Demidchik et al., 2010).

Much higher sodium concentrations could be tolerated in vacuoles, one of the functions of the organelle is to sequester and isolate sodium. Concentrations of sodium in vacuoles may exceed 0.5-1 M being up to ten times over the cytoplasmic sodium concentrations (eg Flowers et al., 1977; Zhao et al., 2005; Flowers and Colmer, 2008) at the expenses of activity of specific iontransport systems (reviewed in: Martinoia et al., 2012). Under salt treatment of $2 \mathrm{M} \mathrm{NaCl}$ for 85 days shoot tissue concentrations of sodium in halophytes Tecticornia were about $2 \mathrm{M}$, so presumably vacuolar $\mathrm{Na}^{+}$concentrations could be over $2 \mathrm{M}$ in the halophytes (English and Colmer, 2013).

The reasons for sodium competing with potassium are that the ions have (1) the same electric charge, $1.6^{*} 10^{-19}$ coulombs, (2) similar cation radii in non-hydrated, about $0.1 \mathrm{~nm}=1.0 \AA$ for sodium cation and $0.14 \mathrm{~nm}=1.4 \AA$ for potassium (diameter being nearly $2-3 \%$ of cell membrane thickness) and (3) hydrated forms, about $3.6 \AA$ for sodium and $3.2 \AA$ for potassium ions (Nightingale, 1959; Collins, 1997; Mähler and Persson, 2012) and, hence, (4) similar surface electric charge densities, which differ about two times (twice higher for nonhydrated sodium according to charge and diameter of the ion). Therefore interactions of $\mathrm{Na}^{+}$and $\mathrm{K}^{+}$with amino acids of protein surfaces, active centers of enzymes, pockets of allosteric regulation or binding of proteins, selectivity filters of ion channels are similar and often differ only several times in selectivity of the interactions. The selectivity depends on the nature and number of interacting amino acids and their spatial location. Molecular dynamics simulations together with conductivity measurements for several proteins and oligopeptides demonstrated up to five times higher affinity of sodium over potassium to the protein surfaces (especially with numerous carboxyl groups; Vrbka et al., 2006). The phenomenon could explain higher destabilizing effect of sodium over potassium on proteins ("salting them out"), which was initially discovered with white proteinaceous part of hen's eggs by Hofmeister in 1888 (Hofmeister, 1888; Kunz et al., 2004). The effect could be the reason why potassium and not sodium is chosen and naturally selected for being the major intracellular monovalent cation, pumped into cells while pumping out sodium cations (Collins, 1997) though sea and ocean water contains more than 40 times higher concentration of sodium.

Under salt stress, for plants it is important to keep higher $\mathrm{K}^{+} / \mathrm{Na}^{+}$ratio (Maathuis and Amtmann, 1999). It is essential, however, to mention that some proteins (due to specific amino acid composition or structural peculiarities) and processes from halophytes are able to withstand higher sodium concentrations without loss of activity (eg. Flowers and Dalmond, 1992; Premkumar et al., 2005); it seems to be the secondary evolutionary adaptation. It is also interesting that cell wall proteins of studied halophytes and also glycophytes did not change their activity within wide range of sodium concentrations, often from 0 to over 0.5-1 M (Thiyagarajah et al., 1996).

\section{Driving Forces and Pathways for Ion Transport to Cells}

Transport of ions is driven by physico-chemical forces including differences of ion concentrations (to be more precise, activities of ions) and differences in electric potential at the sides of membranes.

Membrane potential of plant cells is routinely measured by microelectrodes with tiny sharp tips around $0.1 \mu \mathrm{m}$ in diameter after impalement of a plant cell of interest (e.g., described in: Blatt, 1991). Recently developed voltage-sensitive fluorescent proteins and dyes (reviewed in: Mutoh et al., 2012) could also be used for at least indications of membrane potential in cell tissues and populations of cells (Matzke and Matzke, 2013). Membrane potentials below $-70 \mathrm{mV}$ and above -200 to $-220 \mathrm{mV}$ are recorded by microelectrodes though values around $-300 \mathrm{mV}$ were also reported; more negative values are often measured in root cells compared to leaf ones (apart from leaf guard cells) (Higinbotham, 1973; L'Roy and Hendrix, 1980; Blatt, 1987; Walker et al., 1995, 1998; Carden et al., 2001, 2003; Shabala and Lew, 2002; Fricke et al., 2006; Murthy and Tester, 2006; Shabala et al., 2006; Volkov and Amtmann, 2006; Armengaud et al., 2009; Hammou et al., 2014). Vacuolar membrane potential is the same or $10-40 \mathrm{mV}$ above the values for cytoplasm with $\mathrm{pH}$ about 2 or over units lower, about 5.0-6.1 or less in vacuoles compared to $\mathrm{pH}=7.0-7.7$ in cytoplasm (e.g., Walker et al., 1995; Carden et al., 2003; Cuin et al., 2003; Martinoia et al., 2012) (Figure 6).

Thermodynamics of ion transport is described by several equations. Nernst equation applied to selectively permeable membrane links ion concentrations at the sides of membrane to the electric potential via the membrane under equilibrium conditions (when net flux of ions via the membrane is absent):

$$
\mathrm{E}_{\mathrm{S}}=\mathrm{E}_{1}-\mathrm{E}_{2}=\mathrm{R}^{*} \mathrm{~T} /\left(\mathrm{Z}_{\mathrm{S}}^{*} \mathrm{~F}\right)^{*} \ln \left(\left[\mathrm{S}_{2}\right] /\left[\mathrm{S}_{1}\right]\right)
$$

(Hille, 2001). Here $\mathrm{E}$ is electric potential, $\mathrm{R}$ is universal gas constant equal to $8.31 \mathrm{~J} /\left(\mathrm{K}^{*}\right.$ mole $)$, $\mathrm{T}$ is temperature in $\mathrm{K}, \mathrm{Z}_{\mathrm{S}}$ is the charge of ion $\mathrm{S}, \mathrm{F}$ is Faraday constant equal to 96,500 $s^{*} \mathrm{~A} /$ mole, $\left[\mathrm{S}_{1}\right]$ and $\left[\mathrm{S}_{2}\right]$ are concentrations of ion $\mathrm{S}$ at the sides of the membrane. Basically, the diffusion of ion $S$ due to different concentrations is equilibrated by distinction in electric potential, which is about $\pm 60 \mathrm{mV}$ (slightly depending on temperature) per 10 -fold difference in concentrations with sign determined by 


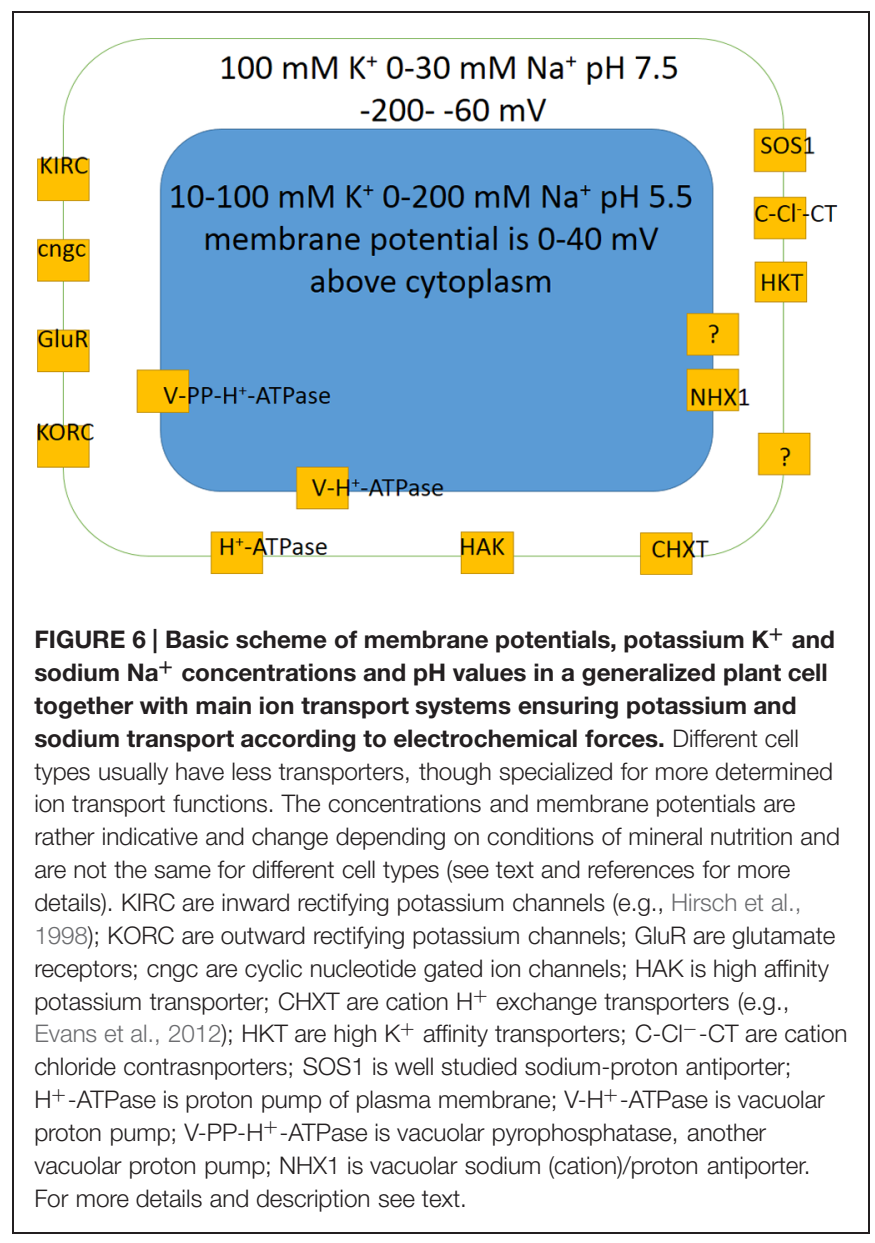

the ion charge. For potassium with typical $100 \mathrm{mM}$ in cytoplasm of epidermal root cell and low $100 \mu \mathrm{M}$ in soil solution the membrane potential to ensure uptake of $\mathrm{K}^{+}$should be below $-180 \mathrm{mV}$ to satisfy the electrochemically downhill transport of $\mathrm{K}^{+}$ions. Lower concentrations of potassium outside the cells may require co-transport of $\mathrm{K}^{+}$with the other ions (e.g., with $\mathrm{H}^{+}$).

For several ion species with specific permeabilities via the membrane a more complicated Goldman-Hodgkin-Katz voltage equation is applicable; it takes into account permeabilities of ions. For sodium, potassium and chloride (obviously more ions to be considered and more components should be added) the equation will be:

$$
\begin{aligned}
\mathrm{E}_{\text {membrane }} & =\mathrm{R}^{*} \mathrm{~T} / \mathrm{F}^{*} \ln \left(\left(\mathrm{P}_{\mathrm{Na}+}\left[\mathrm{Na}^{+}\right]_{\text {out }}+\mathrm{P}_{\mathrm{K}+}\left[\mathrm{K}^{+}\right]_{\text {out }}+\right.\right. \\
& \left.\mathrm{P}_{\mathrm{Cl}-}\left[\mathrm{Cl}^{-}\right]_{\text {in }}\right) /\left(\mathrm{P}_{\mathrm{Na}+}\left[\mathrm{Na}^{+}\right]_{\text {in }}+\mathrm{P}_{\mathrm{K}+}\left[\mathrm{K}^{+}\right]_{\text {in }}+\right. \\
& \left.\left.\mathrm{P}_{\mathrm{Cl}-}\left[\mathrm{Cl}^{-}\right]_{\text {out }}\right)\right)
\end{aligned}
$$

where $\mathrm{E}_{\text {membrane }}$ is membrane potential via the membrane (or $\mathrm{E}_{\text {reversal }}$ with zero net ion current via the membrane), $\mathrm{P}$ are permeabilities of the corresponding ions and [] stands for concentrations of the ions (Hille, 2001). Usually potassium permeability is dominating and membrane potential is close to $\mathrm{E}_{\text {reversal }}$ of $\mathrm{K}^{+}$, though may change and depend on cell type. Active plasma membrane proton pump $\mathrm{H}^{+}$-ATPase (reviewed e.g., in: Palmgren, 2001) shifts membrane potential to more negative values compared to the calculated $\mathrm{E}_{\text {reversal }}$ for $\mathrm{K}^{+}$.

Transport of most ions including $\mathrm{Na}^{+}$and $\mathrm{K}^{+}$in plants occurs passively (following the electrochemical forces) via ion-selective proteinaceous pores of ion channels. Most ion channels can change their conformation from open to close states and vice versa (so called "gating") under applied voltages or after binding ligands and regulators. Another pathway is via proteinaceous transporters with slower transport rates. Ion transport via ion channels is electrogenic since ions carry electric charge, while transporters realize electrogenic or non-electrogenic transport, transporting one ion or co-transporting/antiporting several charged ions in one or opposite directions, correspondingly.

Co-transport of several ions or even small molecules may add extra energy for transport (Figure 7). For example, HAK transporters presumably co-transport $\mathrm{K}^{+}$together with $\mathrm{H}^{+}$ (Banuelos et al., 1995; Rodriguez-Navarro, 2000; Grabov, 2007), which gives several orders of concentration differences extra due to transport of $\mathrm{H}^{+}$according to electric charge. Membrane potential of $-180 \mathrm{mV}$ potentially allows potassium uptake, when co-transported with $\mathrm{H}^{+}$with, e.g., stoichiometry 1:1 under similar external $\mathrm{pH}$ to $\mathrm{pH}$ of cytoplasm, against $10^{6}$ differences in $\mathrm{K}^{+}$concentrations (e.g., Rodriguez-Navarro, 2000). Higher concentrative capacity could be achieved using also $\mathrm{pH}$ differences or higher number of protons per $\mathrm{K}^{+}$; cytoplasmic $\mathrm{pH}$ is about 7.5 and external low $\mathrm{pH}$ of 4 will add over three orders of concentration more. The surprising example is described for yeast Schwanniomyces occidentalis, which was reported to deplete external potassium to $0.03 \mu \mathrm{M}$, presumably taking up $\mathrm{K}^{+}$against $3,000,000$ differences in concentrations

putside
pH 7.5
FIGURE 7 | Simplified scheme demonstrating principles of ion
transport via membrane. Voltage difference below -180 mV allows
potassium transport against 1000-fold concentration difference via
potassium-selective pore of ion channel 1. Similar thermodynamically
favorable potassium transport with lower rates and specific mechanism is
facilitated by potassium transporter 2 . Transporters 2 and 3 are
$\mathrm{H}^{+} / \mathrm{K}^{+}$-cotransporters, they co-transport one or two $\mathrm{H}^{+}$per $\mathrm{K}^{+} ; \mathrm{H}^{+}$is
transported according to voltage difference, hence adding energy for $\mathrm{K}^{+}$
transport. Transporters 2 and 3 can potentially lead to inward transport of $\mathrm{K}^{+}$
against over 1,000,000 concentration difference; their functioning depends
also on pH difference across membrane. More details are in the text.


(assuming over $100 \mathrm{mM}$ of cytoplasmic $\mathrm{K}^{+}$) due to HAK transporters (Banuelos et al., 1995). Much higher concentrations, around $80 \mu \mathrm{M}$, arising from $\mathrm{K}^{+}$contamination from agar and the other chemicals (Armengaud et al., 2009; Kellermeier et al., 2014) (though contamination from agar was estimated at 1-3 $\mu \mathrm{M}$ : Kellermeier et al., 2014) resulted in symptoms of severe potassium deficiency in Arabidopsis and essentially changed transcription profile in roots and shoots of the plants (Armengaud et al., 2004), so more detailed examination with special attention to transport systems of different species (e.g., Coskun and Kronzucker, 2013) is required. Potentially new transporters and ion channels from different organisms could be a source of diversity and comparison for the existing pool of membrane transport proteins and for creating novel artificial transporters.

A set of transporters and ion channels is specific for cell types and organisms, includes tens and more distinct characterized so far proteins, which often form heteromers with variable properties and regulation (Figure 6; e.g., reviewed in: Isayenkov, 2012). Detailed analysis of genome sequences of salt-sensitive model plant Arabidopsis revealed that about $5 \%$ of about 25,000 genes of the plant potentially encode membrane transport proteins; the genes of about 880 proteins are classified in 46 unique groups, while genes of cation channels/transporters predict for coding over 150 proteins (Mäser et al., 2001). Special databases include information about transport proteins, e.g., plant membrane transport database http://aramemnon.uni-koeln.de/; http://www.yeastgenome.org/ is a useful source of information for yeast proteins including yeast membrane transport proteins.

\section{Cell Size-Volume-Surface/Volume Ratio and Effects of Cell Wall}

Interestingly, cell surface/volume ratio has an effect on ion concentration under the same ion fluxes (Figure 8). The sizes of cells within a plant differ orders of magnitude. Cells of xylem parenchyma in roots of dicot Arabidopsis are less than $5 \mu \mathrm{m}$ in diameter with length often below 20-30 $\mu \mathrm{m}$ (eg: Dolan et al., 1993; Ivanov, 1997; Kurup et al., 2005; Verbelen et al., 2006; Ivanov and Dubrovsky, 2013); the cells could be isolated and result in protoplasts of about $10 \mu \mathrm{m}$ in diameter compared to larger $20 \mu \mathrm{m}$ epidermal protoplasts from root elongation zone or $15-25 \mu \mathrm{m}$ protoplasts from root cortex parenchyma cells and the other root tissues (Demidchik and Tester, 2002; Demidchik et al., 2002a; Volkov and Amtmann, 2006). The volumes would correspond to $4 / 3^{*} \pi^{*} R^{3}$ that is about $500 \mathrm{fL}$ for $10 \mu \mathrm{m}$ protoplasts and about $8 \mathrm{pL}$ for $25 \mu \mathrm{m}$ protoplasts.

Cells in leaf epidermis of several monocots are quite large. Barley epidermal leaf cells could be up to $2 \mathrm{~mm}$ long and about 25-30 $\mu \mathrm{m}$ wide with nearly square cross-section, thus reaching volume over $1000 \mathrm{pL}$ (Volkov et al., 2007). Several studies involved isolated protoplasts from barley leaf epidermal cells and reported $60 \mu \mathrm{m}(100 \mathrm{pL})$ protoplasts (Dietz et al., 1992), $40 \mu \mathrm{m}$ (from 20 to $80 \mu \mathrm{m}$ ) ( $30 \mathrm{pL}$, from to 4 to $250 \mathrm{pL}$ ) protoplasts (Karley et al., 2000), 25 pL protoplasts with large variations (over
10 times) in volume (Volkov et al., 2007). It is worth mentioning that about $99 \%$ of large epidermal leaf protoplasts could be occupied by vacuole (Winter et al., 1994).

Assuming volumes of usual plant cells within $500 \mathrm{fL}$ to $1000 \mathrm{pL}$, the calculated surface to volume ratios will differ about

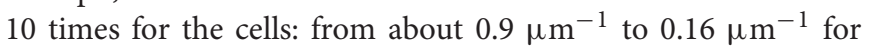
oblong cells within plant tissues. The larger cells need higher ion fluxes or larger time for the same concentration changes.

Effects of cell walls on ion transport are well known though not often remembered and studied in detail (Figure 9). They include changes of cell membrane potential depending on ion composition of ambient medium due to fixed electric charges in cell walls, assumed ion-rectifying properties of cell walls and expected effect of shrinking and swelling of cell walls on mechanosensitive ion channels. Effects of cell walls on ion buffering and ion concentrations have more experimental evidence. For example, protoplasts isolated from bean leaf mesophyll did not show $\mathrm{NaCl}$-induced calcium efflux compared to mesophyll tissue (Shabala and Newman, 2000). Salt-induced $\mathrm{H}^{+}$efflux also differed between protoplasts compared to tissue, so, presumably, all the $\mathrm{Ca}^{2+}$ efflux over an hour of measurement was from calcium ion exchange stores of cell walls (Shabala and Newman, 2000).

\section{Ion Channels vs. Ion Transporters: More about Pathways of Ion Transport to Cells}

One of disputable questions of ion transport is about the relative role of ion channels and transporters in transport. It is commonly accepted that ion channels in an open state/conformation allow passage of over $10^{6}-10^{8}$ ions per second via a selective pore formed within a protein molecule. The diameter of the pore is determined by the molecular structure of ion channel, from $12 \AA$ for potassium channel KcsA with narrow part of $4 \AA$ in diameter (e.g., Doyle et al., 1998; Jiang et al., 2002; MacKinnon, 2004) to $15 \AA$ and even $28 \AA$ diameters of pores for the general bacterial porins with low selectivity and permitted passage for small hydrophilic molecules (about $6 \AA$ pores for the highly selective porins) (e.g., Galdiero et al., 2012). The diameter of the pore and amino acids lining it essentially determine the ion selectivity of ion channel and potential number of passing ions per unit of time. The selectivity could be, for example, over 1,000 for $\mathrm{K}^{+}$over $\mathrm{Na}^{+}$in potassium selective ion channels or over 10 for $\mathrm{Na}^{+}$over $\mathrm{K}^{+}$in sodium selective channels due to special selectivity filters with conserved amino acids for specific channel types. Often amino acid sequence glycine-tyrosineglycine $(\mathrm{GYG})$ indicates selectivity for $\mathrm{K}^{+}$, introducing mutations into the pore to change the amino acids converted potassium selective ion channels to non-selective ones (Heginbotham et al., 1992). The interactions of ions with the protein molecule of ion channel are not well understood yet and probably involve non-electrostatic ion-ion interactions, van der Waals forces, interaction with water molecules and numerous other interactions. Several methods of modeling and simulations of molecular dynamics are applied within at least the last 30 years; sharp increase in computing power allowed to include the lipid 

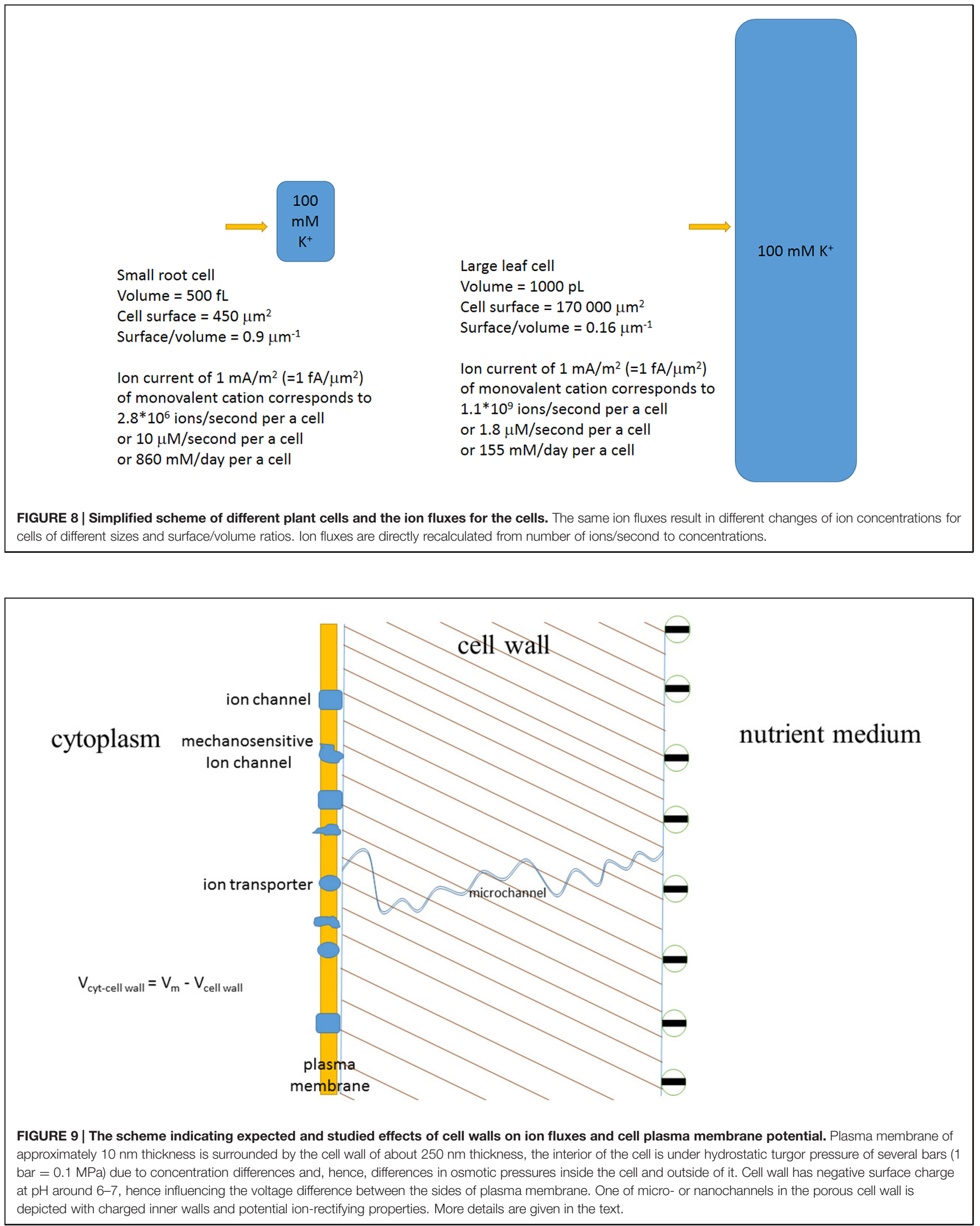
environment of membranes, $\mathrm{pH}$ and the known biochemical factors and regulators to the models (e.g., reviewed in: Maffeo et al., 2012).

Direct measurements are the basement for investigating ion fluxes via ion channels; they provide information about permeating ions, number of ions per second, selectivity and complex transitions of protein molecules of ion channels (gating) during the transport processes. Indeed, a small current of $1 \mathrm{pA}$ corresponds to $10^{-12} \mathrm{~A} /\left(1.6^{*} 10^{-19}\right.$ coulombs $) \approx 6^{*} 10^{6}$ ions/second $\left(1.6^{*} 10^{-19}\right.$ coulombs is elementary charge, a charge of monovalent cation), while most ion channels demonstrate much larger electric currents with complex voltage-dependent patterns of open-closed states (Figure 10).

Transporters could be considered as enzymes where conformational changes of a protein molecule are required for a complete transport cycle of ions (e.g., Gadsby, 2009). Turnover rate of the transporter is the number of complete transport cycles performed per second (e.g., Longpré and Lapointe, 2011). The lower estimate for turnover rate of transporters is the activity of ion pumps. Plant plasma membrane $\mathrm{H}^{+}$-ATPase pumps about 100 ions per a second (Sze et al., 1999). The value is comparable to $20-100 \mathrm{H}^{+}$per second by yeast plasma membrane ATPase Pmal (Serrano, 1988) and turnover rate of $160 \mathrm{~s}^{-1}$ of animal $\mathrm{Na}^{+} / \mathrm{K}^{+}$-ATPase (Skou, 1998). Similar or even lower turnover rates, from 3 to $60 \mathrm{~s}^{-1}$, were shown for sodium/glucose cotransporter (Longpré and Lapointe, 2011 and references therein), while turnover rate about $500 \mathrm{~s}^{-1}$ was estimated for sucrose $/ \mathrm{H}^{+}$co-transporter from maize ZmSUT1 (Carpaneto et al., 2010). The highest possible turnover rate for activity of ion transporters could be assessed from protein structure studies and frequency of conformational changes with estimated upper limit of $10^{6} \mathrm{~s}^{-1}$ (Chakrapani and Auerbach, 2005), which seems to be an overestimated value. A more realistic value for the fast transporters is around 10,000 ions/second, when they are mutated and have accelerated turnover rate (Gadsby, 2009). A higher value of 100,000 ions per second was reported for $\mathrm{Cl}^{-} / \mathrm{H}^{+}$antiporter $\mathrm{ClC}-5$, which is rather a unique type of transporter similar to $\mathrm{ClC}$ channels (Zdebik et al., 2008).

Mechanisms of ion transport by transporters are less understood than transport via pores of ion channels, though the genes of transporters are sequenced and well-studied. Briefly, several mechanisms are expected for different transporters and described below.

HKT transporters with at least eight transmembrane domains could be similar to ion channels, they form a specific ion-selective pore with properties distinct from the pore of ion channels according to basic crystal structure analysis (Cao et al., 2011; reviewed in: Yamaguchi et al., 2013). HKT transporters can electrically resemble ion channels with similar IV curve, reversal potential of ion current mediated by HKT can shift following ion concentrations inside and outside the cell. The phenomenon is observed in Xenopus oocytes heterologously expressing different HKT transporters (Jabnoune et al., 2009; Almeida et al., 2014; de Almeida, 2014), where rectification and Nernstian shift (according to Nernst equation for ion concentrations and voltages) in reversal potential were measured. Pore of HKT transporters has selectivity filter in the first transmembrane domain with conserved glycine for $\mathrm{K}^{+}$-selective and serine for $\mathrm{Na}^{+}$-selective HKT transporters (reviewed in Yamaguchi et al., 2013; de Almeida, 2014). An extra amino acid constriction with arginine residue in the last transmembrane domain makes an additional energy barrier for ion transport (Kato et al., 2007; Cao et al., 2011; reviewed in: Yamaguchi et al., 2013; Benito et al., 2014; de Almeida, 2014). Selectivity of HKT transporters for $\mathrm{Na}^{+}$or $\mathrm{K}^{+}$could be altered by amino acid substitutions, while $\mathrm{K}^{+} / \mathrm{Na}^{+}$symport or $\mathrm{Na}^{+}$uniport are exhibited by different HKT transporters and even varied from $\mathrm{K}^{+} / \mathrm{Na}^{+}$symport to $\mathrm{Na}^{+}$ uniport depending on the cation concentrations (Mian et al., 2011; Almeida et al., 2014; reviewed in Almeida et al., 2013; Waters et al., 2013; de Almeida, 2014). Some HKT transporters symport $\mathrm{K}^{+}$with $\mathrm{Na}^{+}$at low $\mathrm{K}^{+}$concentrations (reviewed in Waters et al., 2013); presumably $\mathrm{Na}^{+}$ion adds energy for cotransport "pushing" $\mathrm{K}^{+}$via the amino acid constrictions (Benito
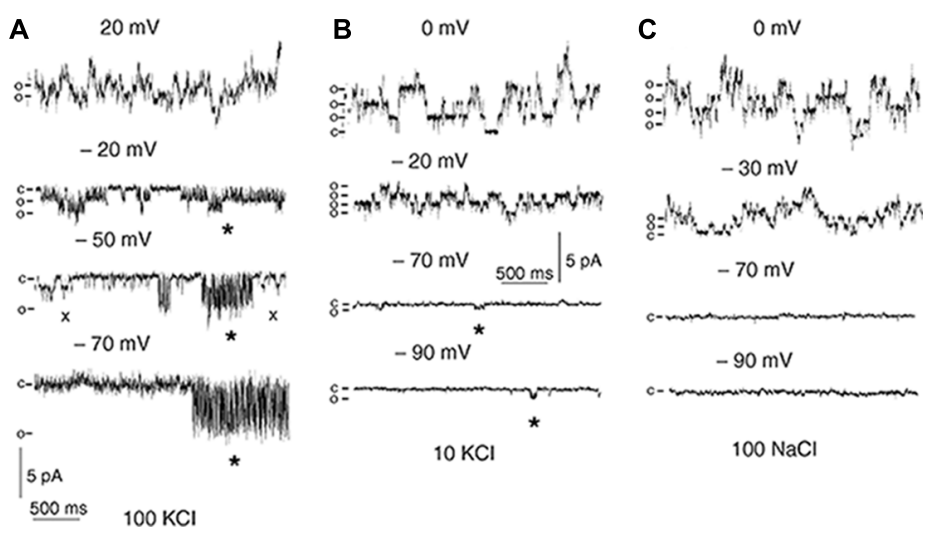

FIGURE 10 | Single-channel recordings in outside-out patches of $\mathbf{T}$. halophila root protoplasts. The pipette solution was $100 \mathrm{mM} \mathrm{KCl}$. The bath solution contained $100 \mathrm{mM} \mathrm{KCl}(\mathbf{A}), 10 \mathrm{mM} \mathrm{KCl}(\mathbf{B})$ or $100 \mathrm{mM} \mathrm{NaCl}(\mathbf{C})$. c, current level with no open channels; o, current levels of single-channel openings. Spiky openings of outward-rectifying channels allowing inward current are indicated with asterisks. Openings of a second type of channel are indicated with crosses. Reproduced from Volkov and Amtmann (2006) with the permission from the publisher John Wiley and Sons. 
et al., 2014), though the exact mechanisms of transport are still to be elucidated.

HAK transporters are not found in animals and Protista (Grabov, 2007). Presumably they co-transport $\mathrm{K}^{+}$together with $\mathrm{H}^{+}$(Banuelos et al., 1995; Rodriguez-Navarro, 2000; Grabov, 2007), but had not been crystallized so far while attempts to express them in Xenopus oocytes failed; therefore mechanisms of ion transport by HAK transporters are not well studied yet. Gene sequences and comparison of HAK transporters predict for 10-14 transmembrane domains (Greiner et al., 2011). Amino acid substitutions within the region between the second and third putative transmembrane domains of Arabidopsis HAK5 transporter essentially changed ion transport selectivity indicating for selectivity filter within the region (Alemán et al., 2014). Lack of putative specific pore similar to HKT transporters suggests that HAK transporters realize specific mechanism for $\mathrm{K}^{+} / \mathrm{H}^{+}$symport (Alemán et al., 2014).

Nhx1 and SOS1 are cation $/ \mathrm{H}^{+}$antiporters. SOS1 has 12 predicted transmembrane domains at the $\mathrm{N}$-terminal part and long C-terminal tail composed of 700 amino acids (Shi et al., 2000), the protein forms homodimers (Núñez-Ramírez et al., 2012). Molecular mechanisms of $\mathrm{Na}^{+} / \mathrm{H}^{+}$antiport by SOS1 are under investigation, though the known crystal structure of bacterial $\mathrm{Na}^{+} / \mathrm{H}^{+}$antiporter NhaA (Hunte et al., 2005) could be a potential basement for understanding transport by both Nhx1 and SOS1. NhaA has 12 transmembrane domains, exists as a dimer, amino acid helices of the protein form negatively charged funnel-like structure, which leads to cytoplasm from the center of membrane and selectively attracts cations. Cationbound Nhal follows transformation and releases cation to the outer side being protonated at the same time at aspartate moieties. Deprotonation, release of $\mathrm{H}^{+}$to cytoplasmic side and return to the initial conformation completes the transport cycle (Hunte et al., 2005). The mechanism with conformation changes limited within a part of the protein makes NhaA one of the fastest transporters; NhaA has activity of catalytic center (turnover rate) about $89,000 \mathrm{~s}^{-1}$ (reviewed in Hunte et al., 2005).

Tonoplast Nhxl could share the same transport mechanism. Discovery of Nhx1 initially provided a molecular basis for $\mathrm{Na}^{+} / \mathrm{H}^{+}$antiport activity of vacuolar membrane. $\mathrm{Na} / \mathrm{H}^{+}$ antiport was measured in tonoplast of several plants: it included amiloride-sensitive transport in vesicles from Beta vulgaris (Blumwald and Poole, 1985) and from mesophyll cells of halophytic plant Mesembryanthemum crystallinum (Barkla et al., 1995), vesicles from roots of NaCl-grown salt-tolerant $P$. maritima, but not salt-sensitive $P$. media (Staal et al., 1991), in preparations from salt-grown barley roots (Garbarino and DuPont, 1988). Gene AtNHX1 of the transporter was cloned from Arabidopsis and rescued some of the salt-sensitive yeast phenotypes under heterologous expression (Gaxiola et al., 1999). Moreover, overexpression of AtNHX1 conferred salinity tolerance to Arabidopsis and significantly increased $\mathrm{Na}^{+} / \mathrm{H}^{+}$antiport activity of vacuolar membrane (Apse et al., 1999). Expression of AtNHX1 in yeast resulted in increased amiloride-sensitive electroneutral $\mathrm{Na}^{+} / \mathrm{H}^{+}$exchange in yeast vacuolar vesicles (Darley et al., 2000). However,
AtNHX1 with 9-11 putative transmembrane domains (reviewed in Rodríguez-Rosales et al., 2009) demonstrated also high $\mathrm{K}^{+} / \mathrm{H}^{+}$exchange capacity depending on regulation by luminal C-terminal domain; the ratio of maximal rates of $\mathrm{K}^{+}$to $\mathrm{Na}^{+}$ transport rose upon binding calmodulin in calcium and $\mathrm{pH}$ dependent manner (Yamaguchi et al., 2003, 2005). Further evidence for role of AtNHX1 in $\mathrm{K}^{+}$transport came from transgenic plants. Overexpression of AtNHX1 in tomato plants conferred higher vacuolar $\mathrm{K}^{+}$under different growth conditions and increased salinity tolerance via retaining intracellular $\mathrm{K}^{+}$ without influencing vacuolar $\mathrm{Na}^{+}$accumulation (Leidi et al., 2010). The simple model of AtNHX1 transporting and localizing excess $\mathrm{Na}^{+}$in vacuole was modified to more complex schemes. It was suggested that AtNHX1 is more important for $\mathrm{K}^{+}$ transport to vacuole thus stimulating $\mathrm{K}^{+}$uptake by roots, then $\mathrm{K}^{+}$ions recycle between cytoplasm and vacuole, while $\mathrm{Na}^{+}$is transported to vacuole and "locked" there (Jiang et al., 2010). Different effects of overexpressed NHX genes on vacuolar $\mathrm{K}^{+}$and $\mathrm{Na}^{+}$concentrations under salt stress and increase in salt tolerance led to conclusions that NHX plays role in both $\mathrm{Na}^{+}$and $\mathrm{K}^{+}$vacuolar transport and $\mathrm{K}^{+}$ homeostasis (reviewed in: Rodríguez-Rosales et al., 2009; Bassil et al., 2012; Yamaguchi et al., 2013; Bassil and Blumwald, 2014).

Unfortunately, ion fluxes via a single transporter (order of several fA or much lower) are below the resolution for electrophysiological measurements. However, potentially the ion currents via at least hundreds and rather thousands or millions of electrogenic ion transporters could be measured under specific conditions. A report about unitary conductance of $\mathrm{Cl}^{-} / \mathrm{H}^{+}$antiporter $\mathrm{ClC}-5$ is an exception, the conductance of $0.45 \mathrm{pS}$ (ion current about $63 \mathrm{fA}$ at $140 \mathrm{mV}$ ) for the transporter was determined from noise analysis of recordings with hundreds/thousands of transporters (Zdebik et al., 2008).

To study their properties, transporters are routinely heterologously expressed in large Xenopus oocytes. Detectable ion currents or fluxes of radioactive tracers are reported following the expression at the background of usually small endogenous electric currents of the oocytes. The successful expression in Xenopus oocytes was reported for several HKT transporters and cation-chloride cotransporters, attempts to record activity of $\mathrm{HAK}, \mathrm{SOS1}$, or Nhx transporters were less fruitful so far (Rodriguez-Navarro, 2000; Liu et al., 2001; Colmenero-Flores et al., 2007; Jabnoune et al., 2009; Rodríguez-Rosales et al., 2009). Mature Xenopus oocytes used for heterologous expression are quite even and have diameter of $1 \mathrm{~mm}$, so measurements could be easily normalized per surface area. A typical surface area of Xenopus oocyte

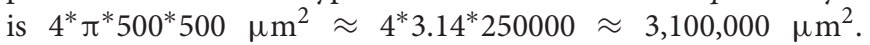
Assuming that the very high recorded values of about $-10 \mu \mathrm{A}$ at $-150 \mathrm{mV}$ for heterologous expression of rice transporter HKT in Xenopus oocytes (Jabnoune et al., 2009) are reasonable and not due to incorrect folding/partial proteolysis/interaction with endogenous transport systems of Xenopus oocytes, we can recalculate the current per a unit of oocyte surface and compare with recordings from plant protoplasts: $-10 \mu \mathrm{A} / 3,100,000 \mu \mathrm{m}^{2}$ $\approx 3 \mathrm{pA} / \mu \mathrm{m}^{2}=3,000 \mathrm{~mA} / \mathrm{m}^{2}$ or about $1 \mathrm{nA}$ per a small root 
protoplast with diameter around $10 \mu \mathrm{m}$. The values are very high and comparable or even much higher (see below) than the ones recorded from activity of ion channels using patch clamp.

Another theoretical estimate is useful for assessing activity of ion transporters expressed in Xenopus oocytes. Assuming the high turnover rate for the transporter around 10,000 and the very high expression of about 10,000 transporters $/ \mu \mathrm{m}^{2}$ (means a transporter per $10^{*} 10 \mathrm{~nm}^{2}$, nearly maximal density due to the physical and steric limitations) we get the possible presumed current per oocyte of Xenopus: 10,000 ions per transporter per second * 3,100,000 $\mu \mathrm{m}^{2} * 10,000$ transporters $/ \mu \mathrm{m}^{2}=3,1^{*} 10^{14}$ ions/second, then taking elementary charge of monovalent ion being $1.6^{*} 10^{-19}$ coulombs, the estimate gives $1.6^{*} 10^{-19}$ coulombs/ion $* 3,1^{*} 10^{14}$ ions/second $\approx 50 \mu \mathrm{A}$ per an oocyte. An excessive order of magnitude could be reasonably explained by a lower level of expression and lower transport rate of a transporter, so gives a reasonable agreement with experimental data and leads to several conclusions.

(1) Transporters can provide sufficient ion currents for registered ion transport under conditions of salinity.

(2) Ion channels are not the only essential pathway for ion transport under salinity.

(3) Balance between relative share of ion transport by ion channels or by ion transporters depends on abundances of the corresponding proteins (ion channels or transporters), their regulation and the other factors (composition of ion solutions, membrane potential etc.). Transporters can provide coupled transport of several ions and potentially may ensure fine-tuning of ion transport, while ion channels provide large ion fluxes when required.

The estimates indicate that total ion current via thousands/millions of electrogenic transporters could be measured and characterized in plant protoplasts using patch clamp in whole-cell configuration (recording sum of all ion currents via the whole membrane). Well-studied non-selective cation channels with low conductance carry small instantaneous currents; potential total current via numerous transporters could be of the same range. Ion current via ion-selective ion channels is described by Goldmann-Hodgkin-Katz equations based on assumption of independent passage of ions via channel pore (or constant electric field along the diffusion zone) (Hille, 2001), additional charges of lipid bilayer and the surface of ion channel can modify the ideal curves (Alcaraz et al., 2004). However, similar to Goldmann-Hodgkin-Katz curves were recorded for HKT transporters expressed in Xenopus oocytes (Jabnoune et al., 2009; de Almeida, 2014).

Recently sodium currents via AtHKT1;1 transporters were presumably measured in Arabidopsis root stelar protoplasts overexpressing AtHKT1;1 (Møller et al., 2009; Xue et al., 2011). Patch clamp experiments recorded about $30 \mathrm{~mA} / \mathrm{m}^{2}$ lower (more negative) currents in $10 \mathrm{mM}$ external $\mathrm{Na}^{+}$and about $50 \mathrm{~mA} / \mathrm{m}^{2}$ lower currents in $25 \mathrm{mM}$ external $\mathrm{Na}^{+}$at $-120 \mathrm{mV}$, when compared to control protoplasts. The currents in AtHKT1;1 overexpressing protoplasts shifted the reversal potential according to external $\mathrm{Na}^{+}$concentrations, so confirmed $\mathrm{Na}^{+}$selectivity. Further study (Xue et al., 2011) compared
$\mathrm{Na}^{+}$and $\mathrm{K}^{+}$currents in root stelar cell protoplasts from wild type (control) and athtk1;1-4 mutant plants lacking AtHKT1;1. Potassium currents were similar (about $-50 \mathrm{pA}$ at $-120 \mathrm{mV}$ in $5 \mathrm{mM}$ internal/50 $\mathrm{mM}$ external $\mathrm{K}^{+}$), while sodium currents were about $-50 \mathrm{pA}$ at $-120 \mathrm{mV}$ in control protoplasts at $50 \mathrm{mM}$ internal/50 $\mathrm{mM}$ external $\mathrm{Na}^{+}$compared to about $-10 \mathrm{pA}$ in athtk1;1-4 mutant ones and demonstrated Nernstian shift according to reversal potential of sodium (Xue et al., 2011). The results pose questions for future study. Earlier it had been demonstrated that non-selective cation currents in similar root protoplasts of Arabidopsis (e.g., Demidchik and Tester, 2002 and see below) are slightly (1.5 times) more selective for potassium over sodium, so predictably athtk1;1-4 mutant protoplasts should have 2-4 times higher sodium currents than measured in (Xue et al., 2011) due to expected non-selective cation currents.

The non-selective cation currents are studied well for root protoplasts, especially in Arabidopsis and carried by cyclic nucleotide gated channels (about 20 genes for Arabidopsis) and glutamate receptors (about 20 genes for Arabidopsis) (see below). One of the possible explanations for the paradox is to assume that nonselective cation currents in root stelar protoplasts of Arabidopsis are highly selective for potassium over sodium; the selectivity was shown for root protoplasts of Thellungiella (Volkov and Amtmann, 2006), salt-tolerant relative of Arabidopsis (Bressan et al., 2001; Inan et al., 2004; Amtmann, 2009). It is important to understand specific tissue and cell type expression of genes and proteins for non-selective cation channels and HKT transporters for characterizing their role in total ion currents. So far, more electrophysiological studies were performed with non-selective cation currents, while HKT transporters were mostly studied using molecular biology with the known genes in heterologous expression systems.

Special modeling for different pores of ion channels will help to understand better the peculiarities of ion currents via ion channels and HKT-like transporters. Pharmacological analysis and profiling of ion currents is also essential together with the further use of mutants (knock out or overexpression) and heterologous expression of the genes of interest in cell culture or in Xenopus oocytes. Non-selective ion currents are well characterized electrophysiologically and pharmacologically, especially for root protoplasts (White, 1993; White and LemtiriChlieh, 1995; Roberts and Tester, 1997; Tyerman et al., 1997; Tyerman and Skerrett, 1998; Demidchik and Tester, 2002; reviewed in: Demidchik et al., 2002b; Volkov and Amtmann, 2006; reviewed in: Demidchik and Maathuis, 2007), less is known for transporters. Recently quinine $(500 \mu \mathrm{M})$ was shown to have slight inhibiting effect on ion currents induced by HKT1;4 transporters from durum wheat after heterologous expression in Xenopus oocytes; $\mathrm{Zn}^{2+}, \mathrm{La}^{3+}, \mathrm{Gd}^{3+}$, or amiloride had no effect (Ben Amar et al., 2014). For cationchloride co-transporter from A. thalina, which was expressed in Xenopus oocytes and presumably transported $\mathrm{Na}^{+}: \mathrm{K}^{+}: 2 \mathrm{Cl}^{-}$ $100 \mu \mathrm{M}$ bumetanide had an inhibiting effect on uptake of radioactive ions similar to analogous animal co-transporters (Colmenero-Flores et al., 2007). Amiloride is shown to inhibit Nhx1 vacuolar $\mathrm{Na}^{+}$(cation)/H ${ }^{+}$antiporter (Barkla et al., 1990; Darley et al., 2000). Experiments with heterologous expression 
of rice HKT transporter OsHKT2;4 in Xenopus oocytes demonstrated channel-like behavior with single channel traces and inhibition by $\mathrm{Ba}^{2+}, \mathrm{La}^{3+}$, and $\mathrm{Gd}^{3+}$ (Lan et al., 2010), however, the properties were not typical for a transporter and further on the results were not confirmed and attributed to endogenous currents of the expression system (Sassi et al., 2012).

A further complication for understanding the pathways of membrane ion transport comes from electroporation experiments (e.g., Pakhomov et al., 2009; Wegner et al., 2011, 2013; Wegner, 2013, 2014). Nanopores with diameter about $1.0-1.8 \mathrm{~nm}$ are formed in lipid membrane bilayer of several animal cell lines and plant protoplasts after (1) voltage pulses of $1 \mathrm{~V}$ and lower to -350 to $+250 \mathrm{mV}$ and (2) also during patch clamp experiments after applied holding voltages above +200$250 \mathrm{mV}$ or below -300 to $-250 \mathrm{mV}$ (Pakhomov et al., 2009; Wegner et al., 2011, 2013; Wegner, 2013). The voltage-induced nanopores existed for minutes and demonstrated selectivity for cations (including even $\left.\mathrm{TEA}^{+}\right)$over anions $\left(\mathrm{Cl}^{-}\right)$and slight selectivity for different cations $\left(\mathrm{Ca}^{2+}\right.$ and $\mathrm{Li}^{+}$were the most permeable); certain similarity to behavior of non-selective cation channels was found (Wegner et al., 2011, 2013; Wegner, 2013). It is a question whether the nanopores appear under physiological conditions in plants (voltages below $-300 \mathrm{mV}$ were recorded for plant cells). Heterologous expression of specific ion channels together with use of mutants, elucidating detailed properties, pharmacological profiles and peculiarities of ion fluxes are required to exclude misinterpretation.

\section{GENETIC ENGINEERING WITH NON-SPECIFIC OR TISSUE-SPECIFIC OVEREXPRESSION/KNOCKOUT/ DISRUPTION OF SPECIFIC TRANSPORTERS MODIFIES SALINITY TOLERANCE}

Several obvious ways to achieve salinity tolerance include: (1) decreasing sodium conductance and increasing potassium/sodium selectivity of plasma membrane of root epidermal cells; (2) increasing sodium efflux by root epidermal cells; (3) increasing sodium accumulation in vacuoles; (4) altering sodium and potassium loading and unloading to xylem and phloem depending on plant strategy to cope with salinity. The strategies had been realized by salt-tolerant plants or revealed in plants overexpressing genes of specific transporters.

Modification of gene activity started after the essential rise and success of molecular methods together with the identification and characterisation of individual ion channels and transporters. Lower sodium conductance and higher $\mathrm{K}^{+} / \mathrm{Na}^{+}$selectivity of root epidermis discovered in halophytes (see above) could be potentially reached in agriculturally important plants by RNA silencing of non-selective cation channels or modifying their expression pattern and regulation. However, still not much is known about the exact genes for the ion channels and importance of the individual genes in sodium uptake. Successful attempts to overexpress or knockout genes of vacuolar proton pump $\mathrm{H}^{+}$-PPase, NHX, HKT, or SOS1-like transporters and to modulate the salinity tolerance of plants had already been reported.

Overexpression of the vacuolar $\mathrm{H}^{+}$-pump would enhance the proton pumping activity at vacuolar membrane and thus permit to accumulate more $\mathrm{Na}^{+}$in vacuoles due to activity of $\mathrm{Na}^{+}$(cation) $/ \mathrm{H}^{+}$antiporters $\mathrm{NHX}$. The choice of $\mathrm{H}^{+}$pyrophosphatase is explained by a single gene required for the protein, while the other vacuolar $\mathrm{H}^{+}$-ATPase is composed of several subunits and needs correct overexpression of several genes (reviewed in e.g., Silva and Gerós, 2009). Overexpression of vacuolar $\mathrm{H}^{+}$-PPase under control of strong non-specific viral $35 S$ promoter sharply increased salinity tolerance in Arabidopsis, to $250 \mathrm{mM}$ of $\mathrm{NaCl}$ (Gaxiola et al., 2001). Overexpressing plants accumulated more sodium and potassium in their leaves and also demonstrated higher drought resistance. Further attempts to overexpress vacuolar $\mathrm{H}^{+}$-PPases from different microbial (D'yakova et al., 2006) and plant species increased salinity tolerance in tobacco (D'yakova et al., 2006; Gao et al., 2006; Li et al., 2014), transgenic rice overexpressing also vacuolar transporter NHX1 (Zhao et al., 2006), in alfalfa (Bao et al., 2009), cotton (Pasapula et al., 2011), tomato (Bhaskaran and Savithramma, 2011), and sugarcane (Kumar et al., 2014). The experiments used $35 \mathrm{~S}$ promoter, $\mathrm{NaCl}$ concentration of $150-$ $400 \mathrm{mM}$ and reported higher $\mathrm{Na}^{+}$concentrations in leaves of overexpressing plants under salt treatment, while $\mathrm{K}^{+}$changes were not consistent between the species (Gao et al., 2006; Zhao et al., 2006; Bao et al., 2009; Bhaskaran and Savithramma, 2011; Li et al., 2014). Gene of vacuolar $\mathrm{H}^{+}$-pyrophosphatase was among salinity tolerance determinants in barley (Shavrukov et al., 2013). Overexpression of vacuolar $\mathrm{H}^{+}$-PPase had also an effect on the whole physiology of plants, for example, increasing root growth via probably auxin transport-associated genes, antioxidant enzymes activities and photosynthetic rate in tobacco (Li et al., 2014). Without salt stress the transgenic plants overexpressing $\mathrm{H}^{+}$-pyrophosphatase under control of $35 S$ promoter demonstrated phenotypes either similar to nontransformed plants (Zhao et al., 2006; Bao et al., 2009; Bhaskaran and Savithramma, 2011), or exhibited improved morphological features (Kumar et al., 2014; Li et al., 2014) or lower osmotic potential in leaves (Gao et al., 2006). Salt treatment for nontransgenic plants resulted in both up- and down-regulation of vacuolar $\mathrm{H}^{+}$-PPase in different species, therefore suggesting an important role of vacuolar $\mathrm{H}^{+}$-ATPase in responses to the stress factor (reviewed in: Silva and Gerós, 2009).

Another candidates for overexpression are vacuolar $\mathrm{NHX}$ genes. Overexpression of AtNHX1 increased salinity tolerance in Arabidopsis to $200 \mathrm{mM} \mathrm{NaCl}$, the overexpressing plants accumulated more $\mathrm{Na}^{+}$compared to wild type and demonstrated higher $\mathrm{Na}^{+} / \mathrm{H}^{+}$exchange activity in isolated leaf vacuoles (Apse et al., 1999). The approach of overexpressing AtNHX1 to improve salinity tolerance proved to be successful for tomato; the transgenic plants accumulated more sodium in leaves but not in fruits at $200 \mathrm{mM} \mathrm{NaCl}$ (Zhang and Blumwald, 2001). Cotton plants with AtNHX1 from Arabidopsis (He et al., 2005), rice overexpressing SsNHX1 from halophyte Suaeda salsa (Zhao 
et al., 2006), tomato with heterologous NHX from Pennisetum glaucum (Bhaskaran and Savithramma, 2011) also showed increased salinity tolerance. Overexpression of NHX did not influence the phenotype of plants under control conditions (Apse et al., 1999; Zhang and Blumwald, 2001; He et al., 2005; Zhao et al., 2006; Bhaskaran and Savithramma, 2011).The results with heterologous expression or overexpression of NHX transporters lead to conclusions that the gene is among determinants and potential candidates for engineering salinity tolerance (e.g., Rodríguez-Rosales et al., 2009; Peleg et al., 2011 with more references for successful overexpression of $N H X$ to increase salinity tolerance in sugar beet, wheat, maize and the other plants). However, the overexpression of NHX was not tissuespecific and under the control of strong promoters, one report did not confirm increase in salinity tolerance in Arabidopsis overexpressing AtNHX1 (Yang et al., 2009). Expression in a tissue-specific manner could be the next step for using NHX to increase salinity tolerance.

The amazing simplicity of the idea to play with the expression of known and functionally well characterized transporters and get salt tolerant or salt sensitive plants is applied to plasma membrane SOS $1 \mathrm{Na}^{+} / \mathrm{H}^{+}$antiporters and $\mathrm{Na}^{+}$or $\mathrm{Na}^{+} / \mathrm{K}^{+} \mathrm{HKT}$ transporters. SOS1 is expressed in (1) epidermal root cells where it participates in sodium efflux and in (2) xylem parenchyma cells where SOS1 may load $\mathrm{Na}^{+}$to xylem under moderate salinity and unloads $\mathrm{Na}^{+}$under high salinity or has more complex mode of xylem loading/unloading (Shi et al., 2000, 2002; Pardo et al., 2006; Oh et al., 2007, 2009a; Olías et al., 2009). Arabidopsis mutants with defects in gene of SOS1 exhibited strong growth inhibition under salt treatment (Wu et al., 1996), which was rescued in sos 1 mutant by overexpression of SOS1 gene under $35 S$ promoter (Shi et al., 2000). Overexpression of SOS1 gene in wild type plants under $35 \mathrm{~S}$ promoter enhanced salinity tolerance of Arabidopsis at 100-200 mM NaCl (Shi et al., 2003; Yang et al., 2009), reduced sodium accumulation in shoots and sodium concentration in xylem sap (Shi et al., 2003). Further on overexpression of SOS1 from A. thaliana increased salinity tolerance in transgenic tobacco (Yue et al., 2012) and in transgenic tall fescue (Ma et al., 2014). SOS1 gene from durum wheat conferred salinity tolerance to sos1 mutant of Arabidopsis (Feki et al., 2014). Interestingly, the effects of overexpression were observed under salt treatment, while in the absence of stress no differences were observed in growth or morphology between wild-type plants and the transgenic lines. Disruption of SOS1 activity by RNA interference in Thellungiella on the opposite resulted in the loss of tolerance of the halophyte indicating importance of $\mathrm{Na}^{+}$efflux and essential role of SOS1 in salinity tolerance (Oh et al., 2009a). RNA interference of SOS1 significantly changed the whole transcriptome of Thellungiella (Oh et al., 2007) and vacuolar $\mathrm{pH}$ under salt treatment (Oh et al., 2009b) proving the complex nature of metabolic and regulatory networks in plants (Figures 2 and 6) and yet the probabilistic chances of success in strict overexpression of specific transporters for salinity tolerance improvement. A more complicated situation emerges due to tissue-specific expression. SOS1 is important for long-distance ion transport and xylem loading/unloading in Arabidopsis (Shi et al., 2002; discussed in: de Boer and Volkov, 2003), sodium partioning between plant organs in tomato (Olías et al., 2009) and ion fluxes in root meristem zone (Guo et al., 2009), therefore attempts to express it in specific tissues could increase salinity tolerance to a higher extent.

Genetic modification of salinity tolerance using HKT transporters was also successful. Analysis of Arabidopsis plants with mutated HKT gene revealed higher salt sensitivity of the mutants under long term stress, higher sodium accumulation in their shoots under mild salinity treatment (Mäser et al., 2002) and suggested that HKT is involved in recirculation of sodium within plants (Berthomieu et al., 2003). Further study confirmed increased sodium in the shoots of Arabidopsis hkt1;1 mutants and clarified that HKT is important for root accumulation of $\mathrm{Na}^{+}$and $\mathrm{Na}^{+}$uptake from xylem in Arabidopsis (Davenport et al., 2007). The next step was to create plants overexpressing HKT (Møller et al., 2009). Arabidopsis plants overexpressing AtHKT under the control of $35 S$ promoter were compared with plants specifically overexpressing HKT in cells of root stele. Pro35S:HKT1;1 plants were salt sensitive probably due to higher $\mathrm{Na}^{+}$uptake by roots while tissue specific overexpression of HKT in stele increased salinity tolerance and reduced sodium accumulation in shoots (Møller et al., 2009). The approach was applied to rice where gene from Arabidopsis AtHKT1;1 was heterologously expressed in root cortex. It resulted in lower shoot $\mathrm{Na}^{+}$concentrations, improved salinity tolerance and involved up- and down-regulation of several membrane transport genes including vacuolar $\mathrm{H}^{+}$pyrophosphatases (Plett et al., 2010). Overexpression of HKT had none (Møller et al., 2009; Plett et al., 2010; Mian et al., 2011) or slight inhibiting pleiotropic effect on growth without $\mathrm{NaCl}$ depending on type of promotor for expression and on plant line studied (Møller et al., 2009; Plett et al., 2010). HKT transporters proved to be important for $\mathrm{Na}^{+}$exclusion in wheat and were transferred from durum wheat to bread wheat by interspecific crossing; the genes gave beneficial effects including higher $\mathrm{K}^{+} / \mathrm{Na}^{+}$ratio in leaves under saline conditions (James et al., 2011). Some plants including barley accumulate $\mathrm{Na}^{+}$in shoots; overexpression of barley HvHKT2; 1 under $35 \mathrm{~S}$ promoter in barley increased salinity tolerance at $100 \mathrm{mM} \mathrm{NaCl}$, but opposite to Arabidopsis increased $\mathrm{Na}^{+}$concentration in xylem and $\mathrm{Na}^{+}$accumulation in barley leaves (Mian et al., 2011). Taken together the results set HKT transporters to potential candidates for engineering salinity tolerance and among the determinants of the trait (reviewed in: Horie et al., 2009; Almeida et al., 2013; Maathuis et al., 2014) together with the above mentioned NHX1, SOS1 and presumably new studied transporters, e.g., similar to CHX21 from Arabidopsis (Hall et al., 2006).

Genes which are important for salinity tolerance in the other groups of organisms and not present in higher plants could also be potential candidates for engineering the trait. Sodium pumping ATPase from moss Physcomitrella patens was cloned and expressed under $35 S$ promoter in rice; plasma membrane expression resulted in higher biomass of transgenic plants compared to control ones after 2 weeks of $50 \mathrm{mM}$ salt treatment. Surprisingly, expression of $\mathrm{Na}^{+}$-ATPase did not influence $\mathrm{Na}^{+}$and $\mathrm{K}^{+}$concentrations in transgenic compared to control plants under any tested conditions, so needs more investigation (Jacobs et al., 2011). Recently a new bacterial 
rhodopsin from Krokinobacter eikastus was discovered; it is the first light-driven $\mathrm{Na}^{+}$pump. This rhodopsin was crystallized and resolved using X-ray; the structural basis for $\mathrm{Na}^{+}$transport was revealed (Gushchin et al., 2015; Kato et al., 2015). The photo switchable sodium pump seems a good simple molecular tool. The initial results are already promising and involve the diverse pool of $\mathrm{Na}^{+}$-ATPases and transporters from yeast, algae and microbes for improving salinity tolerance in plants.

\section{PERSPECTIVES OF PROTEIN ENGINEERING. STRUCTURE-FUNCTION STUDIES AND POTENTIAL FUTURE FOR EXPRESSION OF NOVEL ION CHANNELS, PUMPS, AND TRANSPORTERS}

Novel opportunities for increasing salinity tolerance in plants are arising with the development of new methods of molecular biology, understanding regulation networks from synthetic biology and growing knowledge about single point mutations changing specific amino acids within molecules of an ion channel or a transporter.

Single amino acid substitutions, e.g., within $\mathrm{K}^{+}$selectivity filter GYG of potassium channels, may change selectivity of the ion channels rendering them from $\mathrm{K}^{+}$selective to non-selective ones (e.g., Heginbotham et al., 1992). Amino acid substitutions within a presumed pore region of HKT transporters are able to alter them from $\mathrm{Na}^{+}$ selective to $\mathrm{Na}^{+}$and $\mathrm{K}^{+}$permeable (e.g., Mäser et al., 2002; de Almeida, 2014). Moreover, the single point mutations could be determining for salinity tolerance, e.g., amino acid substitution V395L in rice transporter OsHKT1;5 presumably explained the salt sensitivity of the rice cultivar (Cotsaftis et al., 2012). Specific single point substitution in Arabidopsis HAK5 transporter (F130S) over 100 times increased affinity for $\mathrm{K}^{+}$under heterologous expression and reduced inhibition constants for $\mathrm{Na}^{+}$and $\mathrm{Cs}^{+}$(Alemán et al., 2014). Effects of single point mutations on the whole pattern of physiology and on phenotype are well known and better studied in human biomedical science when inherited diseases cystic fibrosis and sickle cell anemia are caused by amino acid substitutions in transport protein CFTR and in hemoglobin, correspondingly.

The knowledge about structure-function correlations of proteins allows to modify the selectivity and create the required properties of ion transport proteins. The way in the direction is to employ the existing and growing information about structurefunction of different ion channels and transporters. Next step is to change their ion selectivity and gating properties according to the requirements using single amino acids mutations and to transform the plants of interest in a tissue-specific or cell-specific manner. Examples of tissue-specific transformation already exist (e.g., Møller et al., 2009; Plett et al., 2010) while the new methods and opportunities are progressing enormously (e.g., Brand et al., 2006; Oszvald et al., 2008 etc.). Recent opportunities to directly edit genome using CRISPR-Cas system could overcome some difficulties and directly modify the expressed genes of ion transport proteins (reviewed in e.g., Shan et al., 2013; Kumar and Jain, 2015).

An alternative approach from synthetic biology is not to modify the existing membrane transport proteins, but to create new ones with desired properties for the further cell-specific transformation (Figure 11). The idea is different from what could be assumed at a first glance. Existing biological organisms emerged over the process of long evolution, when previous "building blocks" and elements were used for the future development and often could not be essentially modified due to intrinsic links within organisms and biological systems. It leaves out the question of ideal design, which is mostly not present in biological organisms. Indeed, they are largely predetermined by the previous evolutional history with intrinsic evolutionary trajectories and evolved under multifactor environment (composition of atmosphere, illumination, temperature, salinity and mineral nutrients, water availability etc., while interactions with the other organisms and biotic interactions are often the most important). A simple example is related to temperature. Ion channels in homoeothermic animals like mammals or birds evolved over hundreds of millions of years under stable conditions and hence differ in many properties from ion channels in plants. Sodium and calcium selective ion channels had not been found in plants while in animals they ensure action potentials in neurons and cardiomyocytes. Specialized highly temperature-sensitive ion channel in animals provide temperature sensation (for example transient receptor potential channels, e.g., Ramsey et al., 2006; Myers et al., 2009). Plants are different, they rely on calcium signaling via non-selective cation channels, may have distinct groups of transporters with specific properties, have no known sodium-selective ion channels and use ion channels with low temperature sensitivity (e.g., plant potassium channels and their regulation are reviewed in: Dreyer and Uozumi, 2011; more general review: Hedrich, 2012). Obviously, cell signaling and regulation in plants have

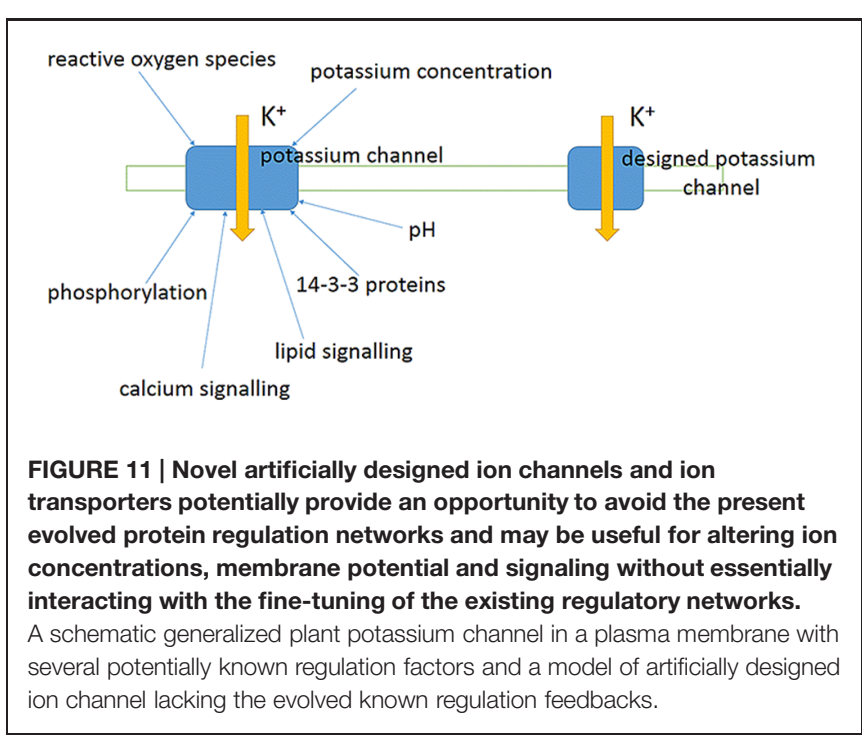


numerous specific peculiarities compared to homoeothermic animals. The differences could be reflected in protein structures, therefore simple comparisons may be misleading. Moreover, plant ion channels and transporters are often functioning at membrane voltages below $-200 \mathrm{mV}$ while animal membranes are usually not experiencing voltages below $-100 \mathrm{mV}$. Structure and functioning of ion transport proteins from yeast, algae, Protista, and microbes could provide more insights for synthetic proteins for plants.

From the point of the above mentioned it seems that attempts to design novel artificial ion channels and transporters with known characterized ion selectivity filters and voltage sensors adding or excluding specific interacting regulatory elements for the proteins might be productive. The ion channels and transporters when expressed in cell-specific manner under controlled conditions and in defined numbers may avoid fine tuning of regulation and potentially could provide shortcuts in natural signaling networks. The appearing opportunities offer new chances to design salt tolerant plants with previously unknown features and wider ranges of regulation circuits and networks. The potential strategy to increase salinity tolerance includes (1) choice of plant, (2) understanding ion transport and features of salinity tolerance for the plant, (3) determining ion fluxes and ion conductances important for $\mathrm{Na}^{+}$and $\mathrm{K}^{+}$ accumulation and compartmentation, (4) modeling ion fluxes and adding/removing in the models ion fluxes and conductances to ensure better nutrient supply and rise of salinity tolerance under salt stress, (5) correlating required changes in ion transport with potential membrane ion transport proteins to realize the ion fluxes, (6) designing specific membrane proteins, (7) expressing the membrane proteins in a tissue-specific manner, (8) checking the salinity tolerance of transgenic plants in laboratory and field experiments. The proposed sequence of events is hypothetical so far and had not been realized yet. However, progress in molecular biology and new ways of thinking from synthetic biology may bring it to fruition and provide new discoveries on the path.

Design of transmembrane proteins is at the very beginning nowadays. Certain structural blocks of the proteins are known better and used for several applications. Voltage-sensors are intensively studied for voltage-gated ion channels and for transporters (Bezanilla, 2008). Moreover, optogenetics needs and already efficiently applies voltage-sensing structural blocks of proteins (Mutoh et al., 2012; Cao et al., 2013; Zou et al., 2014). Selectivity filters of ion channels and transporters are also known and under investigation. Addition of regulatory domains for binding depends on our current information and new endeavors to understand protein-protein interactions and regulation. The further tissue-specific expression and cell-specific localisation of the proteins to be realized via signal peptides and tissue-specific

\section{REFERENCES}

Akhromeeva, T. S., Kurdyumov, S. P., Malinetskii, G. G., and Samarskii, A. A. (1989). Nonstationary dissipative structures and diffusion-induced chaos in nonlinear media. Physics. Rep. 176, 5-6. doi: 10.1016/0370-1573(89)9 0001-X promoters. Problems, strategies and perspectives for engineering novel membrane proteins and re-engineering the existing ones are widely discussed and reviewed (e.g., Grosse et al., 2011; Subramanyam and Colecraft, 2015). De novo design, synthesis confirmed by $\mathrm{X}$-ray structure of $\mathrm{Zn}^{2+}$-transporting four-helix transmembrane protein bundle is a recent experimental advance (Joh et al., 2014). The $\mathrm{Zn}^{2+}$-transport activity of the novel protein was confirmed in functional assays (Joh et al., 2014) proving feasibility of the approach and setting engineering of membrane proteins to a new higher level.

\section{CONCLUSION AND PERSPECTIVES}

Development of agriculture often coincides with salinization of the used land, which is later not available for agricultural plants and inhabited by natural halophyte plants. The problem exists since collapse of Sumer civilization about 4000 years ago due to improper agricultural techniques. Recent decades added modern plant physiology, biophysics, molecular and systems biology to pure agriculture and breeding for creating salt-tolerant crops and agriculturally important plants. New information about individual ion transport systems gave solid physical basis for improving salinity tolerance of plants. Emerging opportunities to overexpress individual genes allowed to sharply increase salinity tolerance in laboratory trials. Growing knowledge in protein engineering and synthetic biology sets novel aims and horizons for producing artificial proteins with predefined transport properties and for designing new regulation networks. Potentially the progress in the direction may lead to partially artificial plants with desired salinity tolerance. The next step would be to fill the huge gap between rapid success in laboratory experiments and field practice. Expectedly the future advances will help to release the problem of salinization of agricultural lands.

\section{ACKNOWLEDGMENTS}

The Author would like to thank colleagues who we worked together over several projects summarized in the Review, Dr Svetlana Bagirova for critical reading and comments on the Manuscript and to bring apologies for not citing all the relevant literature sources due to the limitations by the volume of the Review. The earlier preprint version of the Review entitled "Salinity tolerance in plants: attempts to manipulate ion transport" was uploaded to repository of electronic preprints arXiv at http://arxiv.org/abs/1411.1553 on the 6th of November 2014.

Akhromeeva, T. S., Kurdyumov, S. P., Malinetskij, G. G., and Samarskij, A. A. (1992). Nonstationary Structures and Diffusion Chaos (Nestatsionarnye Struktury i Diffuznyj Khaos). Moskva: Nauka Publisher, 544.

Alcaraz, A., Nestorovich, E. M., Aguilella-Arzo, M., Aguilella, V. M., and Bezrukov, S. M. (2004). Salting out the ionic selectivity of a wide channel: the asymmetry of OmpF. Biophys. J. 87, 943-957. doi: 10.1529/biophysj.104/043414 
Alemán, F., Caballero, F., Ródenas, R., Rivero, R. M., Martínez, V., and Rubio, F. (2014). The F130S point mutation in the Arabidopsis high-affinity $\mathrm{K}^{+}$ transporter AtHAK5 increases $\mathrm{K}^{+}$over $\mathrm{Na}^{+}$and $\mathrm{Cs}^{+}$selectivity and confers $\mathrm{Na}^{+}$and $\mathrm{Cs}^{+}$tolerance to yeast under heterologous expression. Front. Plant Sci. 5:430. doi: 10.3389/fpls.2014.00430

Alemán, F., Nieves-Cordones, M., Martínez, V., and Rubio, F. (2009). Potassium/sodium steady-state homeostasis in Thellungiella halophila and Arabidopsis thaliana under long-term salinity conditions. Plant Sci. 176, 768774. doi: 10.1016/j.plantsci.2009.02.020

Almeida, P., Katschnig, D., and de Boer, A. H. (2013). HKT transporters-state of the art. Int. J. Mol. Sci. 14, 20359-20385. doi: 10.3390/ijms141020359

Almeida, P. M. F., de Boer, G. J., and de Boer, A. H. (2014). Assessment of natural variation in the first pore domain of the tomato HKT1;2 transporter and characterization of mutated versions of SIHKT1;2 expressed in Xenopus laevis oocytes and via complementation of the salt sensitive athkt1;1 mutant. Front. Plant Sci. 5:600. doi: 10.3389/fpls.2014.00600

Amtmann, A. (2009). Learning from evolution: thellungiella generates new knowledge on essential and critical components of abiotic stress tolerance in plants. Mol. Plant 2, 3-12. doi: 10.1093/mp/ssn094

Apse, M. P., Aharon, G. S., Snedden, W. A., and Blumwald, E. (1999). Salt tolerance conferred by overexpression of a vacuolar $\mathrm{Na}^{+} / \mathrm{H}^{+}$antiport in Arabidopsis. Science 285, 1256-1258. doi: 10.1126/science.285.5431.1256

Armengaud, P., Breitling, R., and Amtmann, A. (2004). The potassium-dependent transcriptome of Arabidopsis reveals a prominent role of jasmonic acid in nutrient signaling. Plant Physiol. 136, 2556-2576. doi: 10.1104/pp.104.046482

Armengaud, P., Sulpice, R., Miller, A. J., Stitt, M., Amtmann, A., and Gibon, Y. (2009). Multilevel analysis of primary metabolism provides new insights into the role of potassium nutrition for glycolysis and nitrogen assimilation in Arabidopsis roots. Plant Physiol. 150, 772-785. doi: 10.1104/pp.108.1 33629

Balnokin, Y. V. (1993). Ionic homeostasis and osmoregulation in halotolerant microalgae. Russian J. Plant Physiol. 40, 567-576.

Balnokin, Y. V., and Popova, L. G. (1994). The ATP-driven $\mathrm{Na}^{+}$-pump in the plasma membrane of the marine unicellular alga, Platymonas viridis. FEBS Lett. 343, 61-64. doi: 10.1016/0014-5793(94)80607-1

Banuelos, M. A., Klein, R. D., Alexander-Bowman, S. J., and Rodriguez-Navarro, A. (1995). A potassium transporter of the yeast Schwanniomyces occidentalis homologous to the Kup system of Escherichia coli has a high concentrative capacity. EMBO J. 14, 3021-3027.

Bao, A. K., Wang, S. M., Wu, G. Q., Xi, J. J., Zhang, J. L., and Wang, C. M. (2009). Overexpression of the Arabidopsis $\mathrm{H}^{+}$-PPase enhanced resistance to salt and drought stress in transgenic alfalfa (Medicago sativa L.). Plant Sci. 176, 232-240. doi: 10.1016/j.plantsci.2008.10.009

Barkla, B. J., Charuk, J. H., Cragoe, E. J., and Blumwald, E. (1990). Photolabeling of tonoplast from sugar beet cell suspensions by [3H]5-(N-Methyl-N-Isobutyl)Amiloride, an inhibitor of the vacuolar $\mathrm{Na}^{+} / \mathrm{H}^{+}$antiport. Plant Physiol. 93, 924-930. doi: 10.1104/pp.93.3.924

Barkla, B. J., Zingarelli, L., Blumwald, E., and Smith, J. (1995). Tonoplast $\mathrm{Na}^{+} / \mathrm{H}^{+}$antiport activity and its energization by the vacuolar $\mathrm{h}+$-atpase in the halophytic plant Mesembryanthemum crystallinum L. Plant Physiol. 109, 549-556.

Bassil, E., and Blumwald, E. (2014). The ins and outs of intracellular ion homeostasis: NHX-type cation/ $\mathrm{H}^{+}$transporters. Curr. Opin. Plant Biol. 22, 1-6. doi: $10.1016 /$ j.pbi.2014.08.002

Bassil, E., Coku, A., and Blumwald, E. (2012). Cellular ion homeostasis: emerging roles of intracellular $\mathrm{NHX} \mathrm{Na}{ }^{+} / \mathrm{H}^{+}$antiporters in plant growth and development. J. Exp. Bot. 63, 5727-5740. doi: 10.1093/jxb/ers250

Bazzanella, A., Lochmann, H., Tomos, A. D., and Bächmann, K. (1998). Determination of inorganic cations and anions in single plant cells by capillary zone electrophoresis. J. Chromatogr. 809, 231-239. doi: 10.1016/S00219673(98)00144-7

Ben Amar, S., Brini, F., Sentenac, H., Masmoudi, K., and Véry, A. A. (2014). Functional characterization in Xenopus oocytes of $\mathrm{Na}^{+}$transport systems from durum wheat reveals diversity among two HKT1;4 transporters. J. Exp. Bot. 65, 213-222. doi: 10.1093/jxb/ert361

Benito, B., Haro, R., Amtmann, A., Cuin, T. A., and Dreyer, I. (2014). The twins $\mathrm{K}^{+}$and $\mathrm{Na}^{+}$in plants. J. Plant Physiol. 171, 723-731. doi: 10.1016/j.jplph.2013.10.014
Bennett, T. H., Flowers, T. J., and Bromham, L. (2013). Repeated evolution of salt-tolerance in grasses. Biol. Lett. 9, 20130029. doi: 10.1098/rsbl.2013.0029

Bental, M., Degani, H., and Avron, M. (1988). 23Na-NMR studies of the intracellular sodium ion concentration in the halotolerant alga Dunaliella salina. Plant Physiol. 87, 813-817. doi: 10.1104/pp.87.4.813

Berthomieu, P., Conéjéro, G., Nublat, A., Brackenbury, W. J., Lambert, C., Savio, C., et al. (2003). Functional analysis of AtHKT1 in Arabidopsis shows that $\mathrm{Na}^{+}$recirculation by the phloem is crucial for salt tolerance. EMBO J. 22, 2004-2014. doi: 10.1093/emboj/cdg207

Bezanilla, F. (2008). How membrane proteins sense voltage. Nat. Rev. Mol. Cell Biol. 9, 323-332. doi: 10.1038/nrm2376

Bhaskaran, S., and Savithramma, D. L. (2011). Co-expression of Pennisetum glaucum vacuolar $\mathrm{Na}^{+} / \mathrm{H}^{+}$antiporter and Arabidopsis $\mathrm{H}^{+}$-pyrophosphatase enhances salt tolerance in transgenic tomato. J. Exp. Bot. 62, 5561-5570. doi: $10.1093 / j x b / e r r 237$

Blatt, M. R. (1987). Electrical characteristics of stomatal guard cells: the ionic basis of the membrane potential and the consequence of potassium chlorides leakage from microelectrodes. Planta 170, 272-287. doi: 10.1007/BF00397898

Blatt, M. R. (1991). “A primer in plant electrophysiological methods,” in Methods in Plant Biochemistry, ed. K. Hostettmann (London: Academic Press), 281-321.

Blumwald, E., and Poole, R. J. (1985). $\mathrm{Na}^{+} / \mathrm{H}^{+}$antiport in isolated tonoplast vesicles from storage tissue of Beta vulgaris. Plant Physiol. 78, 163-167. doi: 10.1104/pp.78.1.163

Brand, L., Hörler, M., Nüesch, E., Vassalli, S., Barrell, P., Yang, W., et al. (2006). A versatile and reliable two-component system for tissue-specific gene induction in Arabidopsis. Plant Physiol. 141, 1194-1204. doi: 10.1104/pp.106.081299

Breckle, S.-W. (2002). "Salinity, halophytes and salt affected natural ecosystems," in Salinity: Environment-Plants-Molecules, eds R. Läuchli and U. Lüttge (The Netherlands: Kluwer Academic Publishers), 53-77.

Breeze, E., Harrison, E., McHattie, S., Hughes, L., Hickman, R., Hill, C., et al. (2011). High-resolution temporal profiling of transcripts during Arabidopsis leaf senescence reveals a distinct chronology of processes and regulation. Plant Cell 23, 873-894. doi: 10.1105/tpc.111.083345

Bressan, R. A., Zhang, C., Zhang, H., Hasegawa, P. M., Bohnert, H. J., and Zhu, J. K. (2001). Learning from the Arabidopsis experience. The next gene search paradigm. Plant Physiol. 127, 1354-1360. doi: 10.1104/pp.010752

Britto, D. T., and Kronzucker, H. J. (2008). Cellular mechanisms of potassium transport in plants. Physiol. Plant. 133, 637-650. doi: 10.1111/j.13993054.2008.01067.x

Britto, D. T., and Kronzucker, H. J. (2013). Flux measurements of cations using radioactive tracers. Methods Mol. Biol. 953, 161-170. doi: 10.1007/978-1-62703152-3_10

Britto, D. T., Szczerba, M. W., and Kronzucker, H. J. (2006). A new, nonperturbing, sampling procedure in tracer exchange measurements. J. Exp. Bot. 57, 1309-1314. doi: 10.1093/jxb/erj105

Cao, G., Platisa, J., Pieribone, V. A., Raccuglia, D., Kunst, M., and Nitabach, M. N. (2013). Genetically targeted optical electrophysiology in intact neural circuits. Cell 154, 904-913. doi: 10.1016/j.cell.2013.07.027

Cao, Y., Jin, X., Huang, H., Derebe, M. G., Levin, E. J., Kabaleeswaran, V., et al. (2011). Crystal structure of a potassium ion transporter, TrkH. Nature 471, 336-340. doi: 10.1038/nature09731

Carden, D. E., Diamond, D., and Miller, A. J. (2001). An improved Na ${ }^{+}$-selective microelectrode for intracellular measurements in plant cells. J. Exp. Bot. 52, 1353-1359. doi: 10.1093/jexbot/52.359.1353

Carden, D. E, Walker, D. J., Flowers, T. J., and Miller, A. J. (2003). Single-cell measurements of the contributions of cytosolic $\mathrm{Na}^{+}$and $\mathrm{K}^{+}$to salt tolerance. Plant Physiol. 131, 676-683. doi: 10.1104/pp.011445

Carpaneto, A., Koepsell, H., Bamberg, E., Hedrich, R., and Geiger, D. (2010). Sucrose- and $\mathrm{H}^{+}$-dependent charge movements associated with the gating of sucrose transporter ZmSUT1. PLoS ONE 5:e12605. doi: 10.1371/journal.pone.0012605

Chakrapani, S., and Auerbach, A. (2005). A speed limit for conformational change of an allosteric membrane protein. Proc. Natl. Acad. Sci. U.S.A. 102, 87-92. doi: 10.1073/pnas.0406777102

Cheeseman, J. M. (1986). Compartmental efflux analysis: an evaluation of the technique and its limitations. Plant Physiol. 80, 1006-1011. doi: 10.1104/pp.80.4.1006 
Chen, J., Xiong, D. Y., Wang, W. H., Hu, W. J., Simon, M., Xiao, Q., et al. (2013). Nitric oxide mediates root $\mathrm{K}^{+} / \mathrm{Na}^{+}$balance in a mangrove plant. PLoS ONE 8:e71543. doi: 10.1371/journal.pone.0071543

Chen, Z., Newman, I., Zhou, M., Mendham, N., Zhang, G., and Shabala, S. (2005). Screening plants for salt tolerance by measuring $\mathrm{K}^{+}$flux: a case study for barley. Plant Cell Environ. 28, 1230-1246. doi: 10.1111/j.1365-3040.2005.01364.x

Collins, K. D. (1997). Charge density-dependent strength of hydration and biological structure. Biophys. J. 72, 65-76. doi: 10.1016/S0006-3495(97)78647-8

Colmenero-Flores, J. M., Martínez, G., Gamba, G., Vázquez, N., Iglesias, D. J., Brumós, J., et al. (2007). Identification and functional characterization of cation-chloride cotransporters in plants. Plant J. 50, 278-292. doi: 10.1111/j.1365-313X.2007.03048.x

Coskun, D., and Kronzucker, H. J. (2013). Complexity of potassium acquisition: how much flows through channels? Plant Signal Behav. 8:e24799. doi: $10.4161 /$ psb. 24799

Cotsaftis, O., Plett, D., Shirley, N., Tester, M., and Hrmova, M. (2012). A two-staged model of $\mathrm{Na}^{+}$exclusion in rice explained by $3 \mathrm{D}$ modeling of HKT transporters and alternative splicing. PLoS ONE 7:e39865. doi: 10.1371/journal.pone.0039865

Cuin, T. A., Betts, S. A., Chalmandrier, R., and Shabala, S. (2008). A root's ability to retain $\mathrm{K}^{+}$correlates with salt tolerance in wheat. J. Exp. Bot. 59, 2697-2706. doi: $10.1093 /$ jxb/ern 128

Cuin, T. A., Miller, A. J., Laurie, S. A., and Leigh, R. A. (2003). Potassium activities in cell compartments of salt-grown barley leaves. J. Exp. Bot. 54, 657-661. doi: $10.1093 / \mathrm{jxb} / \mathrm{erg} 072$

Cuin, T. A., and Shabala, S. (2007a). Amino acids regulate salinity-induced potassium efflux in barley root epidermis. Planta 225, 753-761. doi: 10.1007/s00425-006-0386-x

Cuin, T. A., and Shabala, S. (2007b). Compatible solutes reduce ROS-induced potassium efflux in Arabidopsis roots. Plant Cell Environ. 30, 875-885. doi: 10.1111/j.1365-3040.2007.01674.x

Cuin, T. A., Zhou, M., Parsons, D., and Shabala, S. (2012). Genetic behaviour of physiological traits conferring cytosolic $\mathrm{K}^{+} / \mathrm{Na}^{+}$homeostasis in wheat. Plant Biol. 14, 438-446. doi: 10.1111/j.1438-8677.2011.00526.x

Darley, C. P., van Wuytswinkel, O. C., van der Woude, K., Mager, W. H., and de Boer, A. H. (2000). Arabidopsis thaliana and Saccharomyces cerevisiae NHX1 genes encode amiloride sensitive electroneutral $\mathrm{Na}^{+} / \mathrm{H}^{+}$exchangers. Biochem. J. 351, 241-249. doi: 10.1042/0264-6021:3510241

Davenport, R. J., Muñoz-Mayor, A., Jha, D., Essah, P. A., Rus, A., and Tester, M. (2007). The $\mathrm{Na}^{+}$transporter AtHKT1;1 controls retrieval of $\mathrm{Na}^{+}$from the xylem in Arabidopsis. Plant Cell Environ. 30, 497-507. doi: 10.1111/j.13653040.2007.01637.x

de Almeida, P. M. F. (2014). The Role of HKT Transporters in Salinity Tolerance of Tomato. Ph.D. thesis, Vrije Universiteit, Amsterdam, 219.

de Boer, A. H. (1985). Xylem/Symplast Ion Exchange: Mechanism and Function in Salt Tolerance and Growth. Ph.D. thesis, Rijksuniversiteit Groningen, Groningen.

de Boer, A. H., and Volkov, V. (2003). Logistics of water and salt transport through the plant: structure and functioning of the xylem. Plant Cell Environ. 26, 87-101. doi: 10.1046/j.1365-3040.2003.00930.x

Demidchik, V., Bowen, H. C., Maathuis, F. J., Shabala, S. N., Tester, M. A., White, P. J., et al. (2002a). Arabidopsis thaliana root non-selective cation channels mediate calcium uptake and are involved in growth. Plant J. 32, 799-808. doi: 10.1046/j.1365-313X.2002.01467.x

Demidchik, V., Davenport, R. J., and Tester, M. (2002b). Nonselective cation channels in plants. Annu. Rev. Plant Biol. 53, 67-107. doi: 10.1146/annurev.arplant.53.091901.161540

Demidchik, V., Cuin, T. A., Svistunenko, D., Smith, S. J., Miller, A. J., Shabala, S., et al. (2010). Arabidopsis root $\mathrm{K}^{+}$-efflux conductance activated by hydroxyl radicals: single-channel properties, genetic basis and involvement in stressinduced cell death. J. Cell Sci. 123, 1468-1479. doi: 10.1242/jcs.064352

Demidchik, V., and Maathuis, F. J. (2007). Physiological roles of nonselective cation channels in plants: from salt stress to signalling and development. New Phytol. 175, 387-404. doi: 10.1111/j.1469-8137.2007.02128.x

Demidchik, V., Shang, Z., Shin, R., Colaço, R., Laohavisit, A., Shabala, S., et al. (2011). Receptor-like activity evoked by extracellular ADP in Arabidopsis root epidermal plasma membrane. Plant Physiol. 156, 1375-1385. doi: $10.1104 /$ pp.111.174722
Demidchik, V., and Tester, M. (2002). Sodium fluxes through nonselective cation channels in the plasma membrane of protoplasts from Arabidopsis roots. Plant Physiol. 128, 379-387. doi: 10.1104/pp.010524

Dietz, K. J., Schramm, M., Betz, M., Busch, H., Dürr, C., and Martinoia, E. (1992). Characterization of the epidermis from barley primary leaves: I. Isolation of epidermal protoplasts. Planta 187, 425-430. doi: 10.1007/BF00199959

Dolan, L., Janmaat, K., Willemsen, V., Linstead, P., Poethig, S., Roberts, K., et al. (1993). Cellular organisation of the Arabidopsis thaliana root. Development 119, 71-84.

D’Onofrio, C., Kader, A., and Lindberg, S. (2005). Uptake of sodium in quince, sugar beet, and wheat protoplasts determined by the fluorescent sodiumbinding dye benzofuran isophthalate. J. Plant Physiol. 162, 421-428. doi: 10.1016/j.jplph.2004.07.017

Doyle, D. A., Cabral, M. J., Pfuetzner, R. A., Kuo, A., Gulbis, J. M., Cohen, S. L., et al. (1998). The structure of the potassium channel: molecular basis of $\mathrm{K}^{+}$ conduction and selectivity. Science 280, 69-77. doi: 10.1126/science.280.5360.69

Dreyer, I., and Uozumi, N. (2011). Potassium channels in plant cells. FEBS J. 278, 4293-4303. doi: 10.1111/j.1742-4658.2011.08371.x

D’yakova, E. V., Rakitin, A. L., Kamionskaya, A. M., Baikov, A. A., Lahti, R., Ravin, N. V., et al. (2006). A study of the effect of expression of the gene encoding the membrane $\mathrm{H}^{+}$-pyrophosphatase of Rhodospirillum rubrum on salt resistance of transgenic tobacco plants. Doklady Biol. Sci. 409, 346-348. doi: 10.1134/S0012496606040247

English, J. P., and Colmer, T. D. (2013). Tolerance of extreme salinity in two stem-succulent halophytes (Tecticornia species). Funct. Plant Biol. 40, 897-912.

Epstein, E. (1966). Dual pattern of ion absorption by plant cells and by plants. Nature 212, 1324-1327. doi: 10.1038/2121324a0

Erdei, L., and Kuiper, P. J. C. (1979). The effect of salinity on growth. Cation Content, $\mathrm{Na}^{+}$-uptake and translocation in salt-sensitive and salttolerant Plantago Species. Physiol. Plant. 47, 95-99. doi: 10.1111/j.13993054.1979.tb03197.x

Evans, A., Hall, D., Pritchard, J., and Newbury, H. J. (2012). The roles of the cation transporters CHX21 and CHX23 in the development of Arabidopsis thaliana. J. Exp. Bot. 63, 59-67. doi: 10.1093/jxb/err271

Feki, K., Quintero, F. J., Khoudi, H., Leidi, E. O., Masmoudi, K., Pardo, J. M., et al. (2014). A constitutively active form of a durum wheat $\mathrm{Na}^{+} / \mathrm{H}^{+}$antiporter SOS1 confers high salt tolerance to transgenic Arabidopsis. Plant Cell Rep. 33, 277-288. doi: 10.1007/s00299-013-1528-9

Flowers, T. J. (1998). Salinisation and horticultural production. Sci. Hortic. 78, 1-4. Flowers, T. J. (2004). Improving crop salt tolerance. J. Exp. Bot. 55, 307-319. doi: $10.1093 / j x b / e r h 003$

Flowers, T. J., and Colmer, T. D. (2008). Salinity tolerance in halophytes. New Phytol. 179, 945-963. doi: 10.1111/j.1469-8137.2008.02531.x

Flowers, T. J., and Dalmond, D. (1992). Protein synthesis in halophytes: the influence of potassium, sodium and magnesium in vitro. Plant Soil 146, 153161. doi: 10.1007/BF00012008

Flowers, T. J., Galal, H. K., and Bromham, L. (2010). Evolution of halophytes: multiple origins of salt tolerance in land plants. Funct. Plant Biol. 37, 604-612. doi: 10.1071/FP09269

Flowers, T. J., Troke, P. F., and Yeo, A. R. (1977). The mechanism of salt tolerance in halophytes. Annu. Rev. Plant Physiol. 28, 89-121. doi: 10.1146/annurev.pp.28.060177.000513

Fricke, W., Akhiyarova, G., Wei, W., Alexandersson, E., Miller, A., Kjellbom, P. O., et al. (2006). The short-term growth response to salt of the developing barley leaf. J. Exp. Bot. 57, 1079-1095. doi: 10.1093/jxb/erj095

Fricke, W., Leigh, R. A., and Tomos, A. D. (1994). Epidermal solute concentrations and osmolality in barley leaves studied at the single-cell level. Planta 192, 317-323. doi: 10.1007/BF00198566

Gadsby, D. C. (2009). Ion channels versus ion pumps: the principal difference, in principle. Nat. Rev. Mol. Cell Biol. 10, 344-352. doi: 10.1038/nrm2668

Galdiero, S., Falanga, A., Cantisani, M., Tarallo, R., Della Pepa, M. E., D'Oriano, V., et al. (2012). Microbe-host interactions: structure and role of Gram-negative bacterial porins. Curr. Protein Pept. Sci. 13, 843-854. doi: $10.2174 / 1389203711213080012$

Gao, F., Gao, Q., Duan, X., Yue, G., Yang, A., and Zhang, J. (2006). Cloning of an $\mathrm{H}^{+}$-PPase gene from Thellungiella halophila and its heterologous expression to improve tobacco salt tolerance. J. Exp. Bot. 57, 3259-3270. doi: $10.1093 / \mathrm{jxb} / \mathrm{erl} 090$ 
Garbarino, J., and DuPont, F. M. (1988). NaCl Induces a $\mathrm{Na}^{+} / \mathrm{H}^{+}$Antiport in tonoplast vesicles from barley roots. Plant Physiol. 86, 231-236. doi: 10.1104/pp.86.1.231

Garnett, T. P., Shabala, S. N., Smethurst, P. J., and Newman, I. A. (2001). Simultaneous measurements of ammonium, nitrate and proton fluxes along the length of eucalypt roots. Plant Soil 236, 55-62. doi: 10.1023/A:1011951413917

Gaxiola, R. A., Li, J., Undurraga, S., Dang, L. M., Allen, G. J., Alper, S. L., et al. (2001). Drought- and salt-tolerant plants result from overexpression of the AVP1 $\mathrm{H}^{+}$-pump. Proc. Natl. Acad. Sci. U.S.A. 98, 11444-11449. doi: 10.1073/pnas.191389398

Gaxiola, R. A., Rao, R., Sherman, A., Grisafi, P., Alper, S. L., and Fink, G. R. (1999). The Arabidopsis thaliana proton transporters. AtNhxl and Avp1, can function in cation detoxification in yeast. Proc. Natl. Acad. Sci. U.S.A. 96, 1480-1485. doi: 10.1073/pnas.96.4.1480

Gilliham, M., Sullivan, W., Tester, M., and Tyerman, S. D. (2006). Simultaneous flux and current measurement from single plant protoplasts reveals a strong link between $\mathrm{K}^{+}$fluxes and current, but no link between $\mathrm{Ca}^{2+}$ fluxes and current. Plant J. 46, 134-144. doi: 10.1111/j.1365-313X.2006.02676.x

Gimmler, H. (2000). Primary sodium plasma membrane ATPases in salttolerant algae: facts and fictions. J. Exp. Bot. 51, 1171-1178. doi: 10.1093/jexbot/51.348.1171

Grabov, A. (2007). Plant KT/KUP/HAK potassium transporters: single family multiple functions. Ann. Bot. 99, 1035-1041. doi: 10.1093/aob/mcm066

Greiner, T., Ramos, J., Alvarez, M. C., Gurnon, J. R., Kang, M., Van Etten, J. L., et al. (2011). Functional HAK/KUP/KT-like potassium transporter encoded by chlorella viruses. Plant J. 68, 977-986. doi: 10.1111/j.1365-313X.2011.04748.x

Grosse, W., Essen, L. O., and Koert, U. (2011). Strategies and perspectives in ionchannel engineering. Chembiochem 12, 830-839. doi: 10.1002/cbic.201000793

Guo, K. M., Babourina, O., and Rengel, Z. (2009). $\mathrm{Na}^{+} / \mathrm{H}^{+}$antiporter activity of the SOS1 gene: lifetime imaging analysis and electrophysiological studies on Arabidopsis seedlings. Physiol. Plant. 137, 155-165. doi: 10.1111/j.13993054.2009.01274.x

Gushchin, I., Shevchenko, V., Polovinkin, V., Kovalev, K., Alekseev, A., Round, E., et al. (2015). Crystal structure of a light-driven sodium pump. Nat. Struct. Mol. Biol. 22, 390-395. doi: 10.1038/nsmb.3002

Hajibagheri, M. A., and Flowers, T. J. (1989). X-ray microanalysis of ion distribution within root cortical cells of the halophyte Suaeda maritima (L.) Dum. Planta 177, 131-134. doi: 10.1007/BF00392163

Hajibagheri, M. A., Flowers, T. J., Collins, J. C., and Yeo, A. R. (1988). A comparison of the methods of X-ray microanalysis. J. Exp. Bot. 39, 279-290. doi: $10.1093 / \mathrm{jxb} / 39.3 .279$

Hall, D., Evans, A. R., Newbury, H. J., and Pritchard, J. (2006). Functional analysis of CHX21: a putative sodium transporter in Arabidopsis. J. Exp. Bot. 57, 1201-1210. doi: 10.1093/jxb/erj092

Hall, J. L., and Flowers, T. J. (1973). The effect of salt on protein synthesis in the halophyte Suaeda maritima. Planta 110, 361-368. doi: 10.1007/BF00387064

Halperin, S. J., and Lynch, J. P. (2003). Effects of salinity on cytosolic $\mathrm{Na}^{+}$and $\mathrm{K}^{+}$in root hairs of Arabidopsis thaliana: in vivo measurements using the fluorescent dyes SBFI and PBFI. J. Exp. Bot. 54, 2035-2043. doi: 10.1093/jxb/erg219

Hammou, K. A., Rubio, L., Fernández, J. A., and García-Sánchez, M. J. (2014). Potassium uptake in the halophyte Halimione portulacoides L. Aellen Environ. Exp. Bot. 107, 15-24. doi: 10.1016/j.envexpbot.2014.05.001

Hansma, P. K., Drake, B., Marti, O., Gould, S. A., and Prater, C. B. (1989). The scanning ion-conductance microscope. Science 243, 641-643. doi: 10.1126/science.2464851

He, C., Yan, J., Shen, G., Fu, L., Holaday, A. S., Auld, D., et al. (2005). Expression of an Arabidopsis vacuolar sodium/proton antiporter gene in cotton improves photosynthetic performance under salt conditions and increases fiber yield in the field. Plant Cell Physiol. 46, 1848-1854. doi: 10.1093/pcp/pci201

Hedrich, R. (2012). Ion Channels in Plants. Physiol. Rev. 92, 1777-1811. doi: 10.1152/physrev.00038.2011

Heginbotham, L., Abramson, T., and MacKinnon, R. (1992). A functional connection between the pores of distantly related ion channels as revealed by mutant $\mathrm{K}^{+}$channels. Science 258, 1152-1155. doi: 10.1126/science.1279807

Higinbotham, N. (1973). Electropotentials of Plant Cells. Annu. Rev. Plant Physiol. 24, 25-46. doi: 10.1146/annurev.pp.24.060173.000325

Hille, B. (2001). Ion Channels and Excitable Membranes, 3rd Edn. (Sunderland, MA: Sinauer Associates), 814.
Hirsch, R. E., Lewis, B. D., Spalding, E. P., and Sussman, M. R. (1998). A role for the AKT1 potassium channel in plant nutrition. Science 280, 918-921. doi: $10.1126 /$ science. 280.5365 .918

Hofmeister, F. (1888). Zur Lehre von der Wirkung der Salze. Archiv Exp. Pathol. Pharmakol. 24, 247-260. doi: 10.1007/BF01918191

Horie, T., Hauser, F., and Schroeder, J. I. (2009). HKT transporter-mediated salinity resistance mechanisms in Arabidopsis and monocot crop plants. Trends Plant Sci. 14, 660-668. doi: 10.1016/j.tplants.2009.08.009

Hughes, F. M. Jr., and Cidlowski, J. A. (1999). Potassium is a critical regulator of apoptotic enzymes in vitro and in vivo. Adv. Enzyme Regul. 39, 157-171. doi: 10.1016/S0065-2571(98)00010-7

Huh, G. H., Damsz, B., Matsumoto, T. K., Reddy, M. P., Rus, A. M., Ibeas, J. I., et al. (2002). Salt causes ion disequilibrium-induced programmed cell death in yeast and plants. Plant J. 29, 649-659. doi: 10.1046/j.0960-7412.2001.01247.x

Hunte, C., Screpanti, E., Venturi, M., Rimon, A., Padan, E., and Michel, H. (2005). Structure of $\mathrm{a} \mathrm{Na}^{+} / \mathrm{H}^{+}$antiporter and insights into mechanism of action and regulation by $\mathrm{pH}$. Nature 435, 1197-1202. doi: 10.1038/nature03692

Inan, G., Zhang, Q., Li, P., Wang, Z., Cao, Z., Zhang, H., et al. (2004). Salt cress. A halophyte and cryophyte Arabidopsis relative model system and its applicability to molecular genetic analyses of growth and development of extremophiles. Plant Physiol. 135, 1718-1737. doi: 10.1104/pp.104.041723

Isayenkov, S. V. (2012). Physiological and molecular aspects of salt stress in plants. Cytol. Genet. 46, 302-318. doi: 10.3103/S0095452712050040

Ivanov, V. B. (1997). Relationship between cell proliferation and transition to elongation in plant roots. Int. J. Dev. Biol. 41, 907-915.

Ivanov, V. B., and Dubrovsky, J. G. (2013). Longitudinal zonation pattern in plant roots: conflicts and solutions. Trends Plant Sci. 18, 237-243. doi: 10.1016/j.tplants.2012.10.002

Ivashikina, N., Becker, D., Ache, P., Meyerhoff, O., Felle, H. H., and Hedrich, R. (2001). $\mathrm{K}^{+}$channel profile and electrical properties of Arabidopsis root hairs. FEBS Lett. 508, 463-469. doi: 10.1016/S0014-5793(01)03114-3

Jabnoune, M., Espeout, S., Mieulet, D., Fizames, C., Verdeil, J. L., Conéjéro, G., et al. (2009). Diversity in expression patterns and functional properties in the rice HKT transporter family. Plant Physiol. 150, 1955-1971. doi: 10.1104/pp.109.138008

Jacobs, A., Ford, K., Kretschmer, J., and Tester, M. (2011). Rice plants expressing the moss sodium pumping ATPase PpENA1 maintain greater biomass production under salt stress. Plant Biotechnol. J. 9, 838-847. doi: 10.1111/j.14677652.2011.00594.x

James, R. A., Blake, C., Byrt, C. S., and Munns, R. (2011). Major genes for $\mathrm{Na}^{+}$exclusion. Nax1 and Nax2 (wheat HKT1;4 and HKT1;5), decrease $\mathrm{Na}^{+}$ accumulation in bread wheat leaves under saline and waterlogged conditions. J. Exp. Bot. 62, 2939-2947. doi: 10.1093/jxb/err003

Jiang, X., Leidi, E. O., and Pardo, J. M. (2010). How do vacuolar NHX exchangers function in plant salt tolerance? Plant Signal Behav. 5, 792-795. doi: 10.4161/psb.5.7.11767

Jiang, Y., Lee, A., Chen, J., Cadene, M., Chait, B. T., and MacKinnon, R. (2002). The open pore conformation of potassium channels. Nature 417, 523-526. doi: $10.1038 / 417523 a$

Joh, N. H., Wang, T., Bhate, M. P., Acharya, R., Wu, Y., Grabe, M., et al. (2014). De novo design of a transmembrane $\mathrm{Zn}^{2+}$-transporting four-helix bundle. Science 6216, 1520-1524. doi: 10.1126/science.1261172

Kader, M. A., and Lindberg, S. (2005). Uptake of sodium in protoplasts of saltsensitive and salt-tolerant cultivars of rice. J. Exp. Bot. 56, 3149-3158. doi: $10.1093 / \mathrm{jxb} / \mathrm{eri3} 12$

Karley, A. J., Leigh, R. A., and Sanders, D. (2000). Differential ion accumulation and ion fluxes in the mesophyll and epidermis of barley. Plant Physiol. 122, 835-844. doi: 10.1104/pp.122.3.835

Kato, H. E., Inoue, K., Abe-Yoshizumi, R., Kato, Y., Ono, H., Konno, M., et al. (2015). Structural basis for $\mathrm{Na}^{+}$transport mechanism by a light-driven $\mathrm{Na}^{+}$ pump. Nature 521, 48-53. doi: 10.1038/nature14322

Kato, N., Akai, M., Zulkifli, L., Matsuda, N., Kato, Y., Goshima, S., et al. (2007). Role of positively charged amino acids in the M2D transmembrane helix of Ktr/Trk/HKT type cation transporters. Channels (Austin) 1, 161-171. doi: $10.4161 /$ chan. 4374

Katsuhara, M., and Kawasaki, T. (1996). Salt stress induced nuclear and DNA degradation in meristematic cells of barley roots. Plant Cell Physiol. 37, 169-173. doi: 10.1093/oxfordjournals.pcp.a028928 
Katz, A., and Avron, M. (1985). Determination of intracellular osmotic volume and sodium concentration in dunaliella. Plant Physiol. 78, 817-820. doi: 10.1104/pp.78.4.817

Kellermeier, F., Armengaud, P., Seditas, T. J., Danku, J., Salt, D. E., and Amtmann, A. (2014). Analysis of the root system architecture of arabidopsis provides a quantitative readout of crosstalk between nutritional signals. Plant Cell 26, 1480-1496. doi: 10.1105/tpc.113.122101

Knowles, A., and Shabala, S. (2004). Overcoming the problem of non-ideal liquid ion exchanger selectivity in microelectrode ion flux measurements. J. Membr. Biol. 202, 51-59. doi: 10.1007/s00232-004-0719-2

Korchev, Y. E., Bashford, C. L., Milovanovic, M., Vodyanoy, I., and Lab, M. J. (1997). Scanning ion conductance microscopy of living cells. Biophys. J. 73, 653-658. doi: 10.1016/S0006-3495(97)78100-1

Korolev, A. V., Tomos, A. D., Bowtell, R., and Farrar, J. F. (2000). Spatial and temporal distribution of solutes in the developing carrot taproot measured at single-cell resolution. J. Exp. Bot. 51, 567-577. doi: 10.1093/jexbot/51.344.56

Kronzucker, H. J., and Britto, D. T. (2011). Sodium transport in plants: a critical review. New Phytol. 189, 54-81. doi: 10.1111/j.1469-8137.2010.03540.x

Kumar, T., Uzma, A. S., Khan, M. R., Abbas, Z., and Ali, G. M. (2014). Genetic Improvement of sugarcane for drought and salinity stress tolerance using arabidopsis vacuolar pyrophosphatase (AVP1) gene. Mol. Biotechnol. 56, 199209. doi: 10.1007/s12033-013-9695-Z

Kumar, V., and Jain, M. (2015). The CRISPR-Cas system for plant genome editing: advances and opportunities. J. Exp. Bot. 66, 47-57. doi: 10.1093/jxb/eru429

Kunz, W., Henle, J., and Ninham, B. W. (2004). Zur Lehre von der Wirkung der Salze' (about the science of the effect of salts): franz Hofmeister's historical papers. Curr. Opin. Colloid Interface Sci. 9, 19-37. doi: 10.1016/j.cocis.2004.05.005

Kurup, S., Runions, J., Köhler, U., Laplaze, L., Hodge, S., and Haseloff, J. (2005) Marking cell lineages in living tissues. Plant J. 42, 444-453. doi: 10.1111/j.1365313X.2005.02386.X

Lab, M. J., Bhargava, A., Wright, P. T., and Gorelik, J. (2013). The scanning ion conductance microscope for cellular physiology. Am. J. Physiol. Heart Circ. Physiol. 304, H1-H11. doi: 10.1152/ajpheart.00499.2012

Lan, W. Z., Wang, W., Wang, S. M., Li, L. G., Buchanan, B. B., Lin, H. X., et al. (2010). A rice high-affinity potassium transporter (HKT) conceals a calciumpermeable cation channel. Proc. Natl. Acad. Sci. U.S.A. 107, 7089-7094. doi: 10.1073/pnas.1000698107

Leidi, E. O., Barragán, V., Rubio, L., El-Hamdaoui, A., Ruiz, M. T., Cubero, B., et al. (2010). The AtNHX1 exchanger mediates potassium compartmentation in vacuoles of transgenic tomato. Plant J. 61, 495-506. doi: 10.1111/j.1365313X.2009.04073.x

Lew, R. R., Levina, N. N., Shabala, L., Anderca, M. I., and Shabala, S. N. (2006). Role of a mitogen-activated protein kinase cascade in ion flux-mediated turgor regulation in fungi. Eukaryot. Cell 5, 480-487. doi: 10.1128/EC.5.3.480487.2006

Li, X., Guo, C., Gu, J., Duan, W., Zhao, M., Ma, C., et al. (2014). Overexpression of VP, a vacuolar $\mathrm{H}^{+}$-pyrophosphatase gene in wheat (Triticum aestivum L.), improves tobacco plant growth under $\mathrm{Pi}$ and $\mathrm{N}$ deprivation, high salinity, and drought. J. Exp. Bot. 65, 683-696. doi: 10.1093/jxb/ert442

Lindberg, S. (1995). In-situ determination of intracellular concentrations of $\mathrm{K}^{+}$ in barley (Hordeum vulgare $\mathrm{L}$. cv. Kara) using the $\mathrm{K}^{+}$-binding fluorescent dye benzofuran isophthalate Planta 195, 525-529. doi: 10.1007/BF00195710

Liu, W., Fairbairn, D. J., Reid, R. J., and Schachtman, D. P. (2001). Characterization of two HKT1 homologues from Eucalyptus camaldulensis that display intrinsic osmosensing capability. Plant Physiol. 127, 283-294.

Liu, Y., Ji, X., Zheng, L., Nie, X., and Wang, Y. (2013). Microarray analysis of transcriptional responses to abscisic acid and salt stress in Arabidopsis thaliana. Int. J. Mol. Sci. 14, 9979-9998. doi: 10.3390/ijms14059979

Longpré, J. P., and Lapointe, J. Y. (2011). Determination of the $\mathrm{Na}^{+}$/glucose cotransporter (SGLT1) turnover rate using the ion-trap technique. Biophys. J. 100, 52-59. doi: 10.1016/j.bpj.2010.11.012

L'Roy, A., and Hendrix, D. L. (1980). Effect of salinity upon cell membrane potential in the marine halophyte, Salicornia bigelovii Torr. Plant Physiol. 65, 544-549. doi: $10.1104 /$ pp.65.3.544

Lüttge, U. (2002). "Mangroves," in Salinity: Environment-Plants-Molecules, eds R. Läuchli and U. Lüttge (The Netherlands: Kluwer Academic Publishers), 113-135.
Ma, D. M., Xu, W. R., Li, H. W., Jin, F. X., Guo, L. N., Wang, J., et al. (2014). Coexpression of the Arabidopsis SOS genes enhances salt tolerance in transgenic tall fescue (Festuca arundinacea Schreb.). Protoplasma 251, 219-231. doi: 10.1007/s00709-013-0540-9

Maathuis, F. J., and Prins, H. B. (1990). Patch clamp studies on root cell vacuoles of a salt-tolerant and a salt-sensitive Plantago species. Plant Physiol. 92, 23-28. doi: $10.1104 /$ pp.92.1.23

Maathuis, F. J. M., Ahmad, I., and Patishtan, J. (2014). Regulation of $\mathrm{Na}^{+}$fluxes in plants. Front. Plant Sci. 5:467. doi: 10.3389/fpls.2014.00467

Maathuis, F. J. M., and Amtmann, A. (1999). $\mathrm{K}^{+}$nutrition and $\mathrm{Na}^{+}$ toxicity: the basis of cellular $\mathrm{K}^{+} / \mathrm{Na}^{+}$ratios. Ann. Bot. 84, 123-133. doi: 10.1006/anbo.1999.0912

Maathuis, F. J. M., Flowers, T. J., and Yeo, A. R. (1992). Sodium-chloride compartmentation in leaf vacuoles of the halophyte Suaeda maritima (L) Dum. and its relation to tonoplast permeability. J. Exp. Bot. 43, 1219-1223. doi: $10.1093 / \mathrm{jxb} / 43.9 .1219$

MacKinnon, R. (2004). Potassium channels and the atomic basis of selective ion conduction (Nobel Lecture). Angew. Chem. Int. Ed. Engl. 43, 4265-4277. doi: 10.1002/anie.200400662

MacRobbie, E. A., and Dainty, J. (1958). Ion transport in Nitellopsis obtusa. J. Gen. Physiol. 42, 335-353. doi: 10.1085/jgp.42.2.335

Maffeo, C., Bhattacharya, S., Yoo, J., Wells, D., and Aksimentiev, A. (2012). Modeling and simulation of ion channels. Chem. Rev. 112, 6250-6284. doi: $10.1021 / \mathrm{cr} 3002609$

Mähler, J., and Persson, I. (2012). A study of the hydration of the alkali metal ions in aqueous solution. Inorg. Chem. 51, 425-438. doi: 10.1021/ic2018693

Malone, M., Leigh, R. A., and Tomos, A. D. (1991). Concentrations of vacuolar inorganic ions in individual cells of intact wheat leaf epidermis. J. Exp. Bot. 42, 305-309. doi: 10.1093/jxb/42.3.305

Martinoia, E., Meyer, S., De Angeli, A., and Nagy, R. (2012). Vacuolar transporters in their physiological context. Annu. Rev. Plant Biol. 63, 183-213. doi: 10.1146/annurev-arplant-042811-105608

Mäser, P., Eckelman, B., Vaidyanathan, R., Horie, T., Fairbairn, D. J., Kubo, M., et al. (2002). Altered shoot/root $\mathrm{Na}^{+}$distribution and bifurcating salt sensitivity in Arabidopsis by genetic disruption of the $\mathrm{Na}^{+}$transporter AtHKT1. FEBS Lett. 531, 157-161. doi: 10.1016/S0014-5793(02)03488-9

Mäser, P., Thomine, S., Schroeder, J. I., Ward, J. M., Hirschi, K., Sze, H., et al. (2001). Phylogenetic relationships within cation transporter families of Arabidopsis. Plant Physiol. 126, 1646-1667. doi: 10.1104/pp.126.4.1646

Masi, A., and Melis, A. (1997). Morphological and molecular changes in the unicellular green alga Dunaliella salina grown under supplemental UV-B radiation: cell characteristics and Photosystem II damage and repair properties. BBA Bioenerget. 1321, 183-193. doi: 10.1016/S0005-2728(97)00054-6

Matzke, A. J., and Matzke, M. (2013). Membrane "potential-omics": toward voltage imaging at the cell population level in roots of living plants. Front. Plant Sci. 4:311. doi: $10.3389 /$ fpls.2013.00311

Mian, A., Oomen, R. J., Isayenkov, S., Sentenac, H., Maathuis, F. J., and Véry, A. A. (2011). Over-expression of an $\mathrm{Na}^{+}$-and $\mathrm{K}^{+}$-permeable HKT transporter in barley improves salt tolerance. Plant J. 68, 468-479. doi: 10.1111/j.1365313X.2011.04701.x

Møller, I. S., Gilliham, M., Jha, D., Mayo, G. M., Roy, S. J., Coates, J. C., et al. (2009). Shoot $\mathrm{Na}^{+}$exclusion and increased salinity tolerance engineered by cell typespecific alteration of $\mathrm{Na}^{+}$transport in Arabidopsis. Plant Cell 21, 2163-2178. doi: $10.1105 /$ tpc. 108.064568

Munns, R., and Tester, M. (2008). Mechanisms of salinity tolerance. Annu. Rev. Plant Biol. 59, 651-681. doi: 10.1146/annurev.arplant.59.032607.092911

Murthy, M., and Tester, M. (2006). Cation currents in protoplasts from the roots of a $\mathrm{Na}^{+}$hyperaccumulating mutant of Capsicum annuum. J. Exp. Bot. 57, 1171-1180. doi: 10.1093/jxb/erj115

Mutoh, H., Akemann, W., and Knöpfel, T. (2012). Genetically engineered fluorescent voltage reporters ACS. Chem. Neurosci. 3, 585-592. doi: $10.1021 / \mathrm{cn} 300041 \mathrm{~b}$

Myers, B. R., Sigal, Y. M., and Julius, D. (2009). Evolution of thermal response properties in a cold-activated TRP channel. PLoS ONE 4:e5741. doi: 10.1371/journal.pone.0005741

Newman, I. A. (2001). Ion transport in roots: measurement of fluxes using ion-selective microelectrodes to characterize transporter function. Plant Cell Environ. 24, 1-14. doi: 10.1046/j.1365-3040.2001.00661.x 
Newman, I. A., Kochian, L. V., Grusak, M. A., and Lucas, W. J. (1987). Fluxes of $\mathrm{H}^{+}$and $\mathrm{K}^{+}$in corn roots: characterization and stoichiometries using ion-selective microelectrodes. Plant Physiol. 84, 1177-1184. doi: 10.1104/pp.84.4.1177

Nightingale, E. R. Jr. (1959). Phenomenological theory of ion solvation. Effective radii of hydrated ions. J. Phys. Chem. 63, 1381-1387. doi: 10.1021/j150579a011

Núñez-Ramírez, R., Sánchez-Barrena, M. J., Villalta, I., Vega, J. F., Pardo, J. M., Quintero, F. J., et al. (2012). Structural insights on the plant saltoverly-sensitive 1 (SOS1) $\mathrm{Na}^{+} / \mathrm{H}^{+}$antiporter. J. Mol. Biol. 424, 283-294. doi: 10.1016/j.jmb.2012.09.015

Oh, D. H., Gong, Q., Ulanov, A., Zhang, Q., Li, Y., Ma, W., et al. (2007). Sodium stress in the halophyte Thellungiella halophila, and transcriptional changes in a thsos1-RNA iterference line. J. Integr. Plant Biol. 49, 1484-1496. doi: 10.1111/j.1672-9072.2007.00548.x

Oh, D. H., Leidi, E., Zhang, Q., Hwang, S. M., Li, Y., Quintero, F. J., et al. (2009a). Loss of halophytism by interference with SOS1 expression. Plant Physiol. 151, 210-222. doi: 10.1104/pp.109.137802

Oh, D. H., Zahir, A., Yun, D. J., Bressan, R. A., and Bohnert, H. J. (2009b). SOS1 and halophytism. Plant Signal. Behav. 4, 1081-1083. doi: 10.4161/psb.4.11.9786

Olías, R., Eljakaoui, Z., Li, J., De Morales, P. A., Marín-Manzano, M. C., Pardo, J. M., et al. (2009). The plasma membrane $\mathrm{Na}^{+} / \mathrm{H}^{+}$antiporter SOS1 is essential for salt tolerance in tomato and affects the partitioning of $\mathrm{Na}^{+}$between plant organs. Plant Cell Environ. 32, 904-916. doi: 10.1111/j.1365-3040.2009.01971.x

Ordoñez, N. M., Marondedze, C., Thomas, L., Pasqualini, S., Shabala, L., Shabala, S., et al. (2014). Cyclic mononucleotides modulate potassium and calcium flux responses to $\mathrm{H} 2 \mathrm{O} 2$ in Arabidopsis roots. FEBS Lett. 588, 1008-1015. doi: 10.1016/j.febslet.2014.01.062

Oszvald, M., Gardonyi, M., Tamas, C., Takacs, I., Jenes, B., Tamas, L., et al. (2008). Development and characterization of a chimaeric tissue-specific promoter in wheat and rice endosperm. In Vitro Cell. Dev. Biol. Plant 44, 1-7. doi: 10.1007/s11627-007-9082-1

Pakhomov, A. G., Bowman, A. M., Ibey, B. L., Andre, F. M., Pakhomova, O. N., and Schoenbach, K. H. (2009). Lipid nanopores can form a stable, ion channel-like conduction pathway in cell membrane. Biochem. Biophys. Res. Commun. 385, 181-186. doi: 10.1016/j.bbrc.2009.05.035

Palmgren, M. G. (2001). PLANT PLASMA MEMBRANE H ${ }^{+}$-ATPases: powerhouses for nutrient uptake. Annu. Rev. Plant. Physiol. Plant Mol. Biol. 52, 817-845. doi: 10.1146/annurev.arplant.52.1.817

Pandolfi, C., Pottosin, I., Cuin, T., Mancuso, S., and Shabala, S. (2010). Specificity of polyamine effects on Nacl-induced ion flux kinetics and salt stress amelioration in plants. Plant Cell Physiol. 51, 422-434. doi: 10.1093/pcp/pcq007

Pang, J. Y., Newman, I., Mendham, N., Zhou, M., and Shabala, S. (2006). Microelectrode ion and $\mathrm{O} 2$ fluxes measurements reveal differential sensitivity of barley root tissues to hypoxia. Plant Cell Environ. 29, 1107-1121. doi: 10.1111/j.1365-3040.2005.01486.x

Pantoja, O., Dainty, J., and Blumwald, E. (1989). Ion channels in vacuoles from halophytes and glycophytes. FEBS Lett. 255, 92-96. doi: 10.1016/00145793(89)81067-1

Pardo, J. M., Cubero, B., Leidi, E. O., and Quintero, F. J. (2006). Alkali cation exchangers: roles in cellular homeostasis and stress tolerance. J. Exp. Bot. 57, 1181-1199. doi: 10.1093/jxb/erj114

Pasapula, V., Shen, G., Kuppu, S., Paez-Valencia, J., Mendoza, M., Hou, P., et al. (2011). Expression of an Arabidopsis vacuolar $\mathrm{H}^{+}$-pyrophosphatase gene (AVP1) in cotton improves drought- and salt tolerance and increases fibre yield in the field conditions. Plant Biotechnol. J. 9, 88-99. doi: 10.1111/j.14677652.2010.00535.x

Peleg, Z., Apse, M. P., and Blumwald, E. (2011). Engineering salinity and waterstress tolerance in crop plants: getting closer to the field. Adv. Bot. Res. 57, 405-443. doi: 10.1016/B978-0-12-387692-8.00012-6

Pick, U., Karni, L., and Avron, M. (1986). Determination of ion content and ion fluxes in the halotolerant alga Dunaliella salina. Plant Physiol. 81, 92-96. doi: 10.1104/pp.81.1.92

Pitman, M. G., and Läuchli, A. (2002). "Global impact of salinity and agricultural ecosystems," in Salinity: Environment-Plants-Molecules, eds R. Läuchli and U. Lüttge (The Netherlands: Kluwer Academic Publishers), 3-20.

Pitman, M. G., Läuchli, A., and Stelzer, R. (1981). Ion distribution in roots of barley seedlings measured by electron probe x-ray microanalysis. Plant Physiol. 68, 673-679. doi: 10.1104/pp.68.3.673
Plett, D., Safwat, G., Gilliham, M., Møller, I. S., Roy, S., Shirley, N., et al. (2010). Improved salinity tolerance of rice through cell type-specific expression of AtHKT1;1. PLoS ONE 5:e12571. doi: 10.1371/journal.pone.0012571

Popova, L. G., Shumkova, G. A., Andreev, I. M., and Balnokin, Y. V. (2005). Functional identification of electrogenic $\mathrm{Na}^{+}$-translocating ATPase in the plasma membrane of the halotolerant microalga Dunaliella maritima. FEBS Lett. 579, 5002-5006. doi: 10.1016/j.febslet.2005.07.087

Premkumar, L., Greenblatt, H. M., Bagashwar, U. K., Savchenko, T., Gokhman, I., Sussman, J. L., et al. (2005). 3D structure of a halotolerant algal carbonic anhydrase predicts halotolerance of a mammalian homolog. Proc. Natl. Acad. Sci. U.S.A. 102, 7493-7498. doi: 10.1073/pnas.0502829102

Rains, D. W., and Epstein, E. (1965). Transport of sodium in plant tissue. Science 148, 1611. doi: 10.1126/science.148.3677.1611

Ramsey, I. S., Delling, M., and Clapham, D. E. (2006). An introduction to TRP channels. Annu. Rev. Physiol. 68, 619-647. doi: 10.1146/annurev. physiol.68.040204.100431

Roberts, S. K., and Tester, M. (1997). A patch clamp study of $\mathrm{Na}^{+}$transport in maize roots. J. Exp. Bot. 48, 431-440. doi: 10.1093/jxb/48

Rodriguez-Navarro, A. (2000). Potassium transport in fungi and plants. BBA Rev. Biomembr. 1469, 1-30. doi: 10.1016/S0304-4157(99)00013-1

Rodríguez-Rosales, M. P., Gálvez, F. J., Huertas, R., Aranda, M. N., Baghour, M., Cagnac, O., et al. (2009). Plant NHX cation/proton antiporters. Plant Signal. Behav. 4, 265-276. doi: 10.4161/psb.4.4.7919

Sassi, A., Mieulet, D., Khan, I., Moreau, B., Gaillard, I., Sentenac, H., et al. (2012). The rice monovalent cation transporter OsHKT2;4: revisited ionic selectivity. Plant Physiol. 160, 498-510. doi: 10.1104/pp.112.194936

Schulze, L. M., Britto, D. T., Li, M., and Kronzucker, H. J. (2012). A pharmacological analysis of high-affinity sodium transport in barley (Hordeum vulgare L.): a $24 \mathrm{Na}^{+} / 42 \mathrm{~K}^{+}$study. J. Exp. Bot. 63, 2479-2489. doi: $10.1093 / \mathrm{jxb} / \mathrm{err} 419$

Serrano, R. (1988). Structure and function of proton translocating ATPase in plasma membranes of plants and fungi. Biochim. Biophys. Acta 947, 1-28. doi: 10.1016/0304-4157(88)90017-2

Serrano, R. (1996). Salt tolerance in plants and microorganisms: toxicity targets and defense mechanisms. Int. Rev. Cytol. 165, 1-52. doi: 10.1016/S00747696(08)62219-6

Shabala, L., Cuin, T. A., Newman, I. A., and Shabala, S. (2005). Salinity-induced ion flux patterns from the excised roots of Arabidopsis sos mutants. Planta 222, 1041-1050. doi: 10.1007/s00425-005-0074-2

Shabala, S. (2006). "Non-invasive microelectrode ion flux measurements in plant stress physiology," in Plant Electrophysiology-Theory and Methods, ed. A. G. Volkov (Berlin: Springer-Verlag), 35-71.

Shabala, S. (2009). Salinity and programmed cell death: unravelling mechanisms for ion specific signalling. J. Exp. Bot. 60, 709-712. doi: 10.1093/jxb/erp013

Shabala, S. (2013). Learning from halophytes: physiological basis and strategies to improve abiotic stress tolerance in crops. Ann. Bot. 112, 1209-1221. doi: $10.1093 / \mathrm{aob} / \mathrm{mct} 205$

Shabala, S., and Bose, J. (2012). "Application of non-invasive microelectrode flux measurements in plant stress physiology," in Plant Electrophysiology-Methods and Cell Electrophysiology, ed. A. G. Volkov (Berlin: Springer-Verlag), 91-126.

Shabala, S., Demidchik, V., Shabala, L., Cuin, T. A., Smith, S. J., Miller, A. J., et al. (2006). Extracellular $\mathrm{Ca}^{+}{ }^{2}$ ameliorates $\mathrm{NaCl}$-induced $\mathrm{K}^{+}$loss from Arabidopsis root and leaf cells by controlling plasma membrane $\mathrm{K}^{+}$-permeable channels. Plant Physiol. 141, 1653-1665. doi: 10.1104/pp.106.082388

Shabala, S., and Newman, I. (2000). Salinity effects on the activity of plasma membrane $\mathrm{H}^{+}$and $\mathrm{Ca}^{2+}$ transporters in bean leaf mesophyll: masking role of the cell wall. Ann. Bot. 85, 681-686. doi: 10.1006/anbo.2000.1131

Shabala, S., Pang, J., Zhou, M., Shabala, L., Cuin, T. A., Nick, P., et al. (2009). Electrical signalling and cytokinins mediate effects of light and root cutting on ion uptake in intact plants. Plant Cell Environ. 32, 194-207. doi: 10.1111/j.13653040.2008.01914. $\mathrm{x}$

Shabala, S. N., and Lew, R. R. (2002). Turgor regulation in osmotically stressed Arabidopsis epidermal root cells. Direct support for the role of inorganic ion uptake as revealed by concurrent flux and cell turgor measurements. Plant Physiol. 129, 290-299. doi: 10.1104/pp.020005

Shan, Q., Wang, Y., Li, J., Zhang, Y., Chen, K., Liang, Z., et al. (2013). Targeted genome modification of crop plants using a CRISPR-Cas system. Nat. Biotechnol. 31, 686-688. doi: 10.1038/nbt.2650 
Shavrukov, Y., Bovill, J., Afzal, I., Hayes, J. E., Roy, S. J., Tester, M., et al. (2013). HVP10 encoding V-PPase is a prime candidate for the barley HvNax3 sodium exclusion gene: evidence from fine mapping and expression analysis. Planta 237, 1111-1122. doi: 10.1007/s00425-012-1827-3

Shi, H., Ishitani, M., Kim, C., and Zhu, J. K. (2000). The Arabidopsis thaliana salt tolerance gene SOS1 encodes a putative $\mathrm{Na}^{+} / \mathrm{H}^{+}$antiporter. Proc. Natl. Acad. Sci. U.S.A. 97, 6896-6901. doi: 10.1073/pnas.120170197

Shi, H., Lee, B. H., Wu, S. J., and Zhu, J. K. (2003). Overexpression of a plasma membrane $\mathrm{Na}^{+} / \mathrm{H}^{+}$antiporter gene improves salt tolerance in Arabidopsis thaliana. Nat. Biotechnol. 21, 81-85. doi: 10.1038/nbt766

Shi, H., Quintero, F. J., Pardo, J. M., and Zhu, J. K. (2002). The putative plasma membrane $\mathrm{Na}^{+} / \mathrm{H}^{+}$antiporter SOS1 controls long-distance $\mathrm{Na}^{+}$transport in plants. Plant Cell 14, 465-477. doi: 10.1105/tpc.010371

Silva, P., and Gerós, H. (2009). Regulation by salt of vacuolar $\mathrm{H}^{+}$-ATPase and $\mathrm{H}^{+}$-pyrophosphatase activities and $\mathrm{Na}^{+} / \mathrm{H}^{+}$exchange. Plant Signal. Behav. 4, 718-726. doi: 10.4161/psb.4.8.9236

Skou, J. C. (1998). Nobel Lecture. The identification of the sodium pump. Biosci. Rep. 18, 155-169.

Spiller, D. G., Wood, C. D., Rand, D. A., and White, M. R. (2010). Measurement of single-cell dynamics. Nature 465, 736-745. doi: 10.1038/nature09232

Staal, M., Maathuis, F. J. M., Elzenga, J. T. M., Overbeek, J. H. M., and Prins, H. B. A. (1991). $\mathrm{Na}^{+} / \mathrm{H}^{+}$antiport activity in tonoplast vesicles from roots of the salt-tolerant Plantago maritima and the salt-sensitive Plantago media. Physiol. Plant. 82, 179-184. doi: 10.1111/j.1399-3054.1991.tb00078.x

Subramanyam, P., and Colecraft, H. M. (2015). Ion channel engineering: perspectives and strategies. J. Mol. Biol. 427, 190-204. doi: 10.1016/j. jmb.2014.09.001

Sun, J., Chen, S. L., Dai, S. X., Wang, R. G., Li, N. Y., Shen, X., et al. (2009). Ion flux profiles and plant ion homeostasis control under salt stress. Plant Signal. Behav. 4, 261-264. doi: 10.4161/psb.4.4.7918

Sze, H., Li, X., and Palmgren, M. G. (1999). Energization of plant cell membranes by $\mathrm{H}^{+}$-pumping ATPases. Regulation and biosynthesis. Plant Cell 11, 677-690.

Taji, T., Seki, M., Satou, M., Sakurai, T., Kobayashi, M., Ishiyama, K., et al. (2004). Comparative genomics in salt tolerance between Arabidopsis and Arabidopsisrelated halophyte salt cress using Arabidopsis microarray. Plant Physiol. 135, 1697-1709. doi: 10.1104/pp.104.039909

Takahashi, F., Tilbrook, J., Trittermann, C., Berger, B., Roy, S. J., Seki, M., et al. (2015). Comparison of leaf sheath transcriptome profiles with physiological traits of bread wheat cultivars under salinity stress. PLOS ONE 10:e0133322. doi: 10.1371/journal.pone.0133322

Thiyagarajah, M., Fry, S. C., and Yeo, A. R. (1996). In vitro salt tolerance of cell wall enzymes from halophytes and glycophytes. J. Exp. Bot. 47, 1717-1724. doi: 10.1093/jxb/47.11.1717

Tyerman, S. D., Beilby, M., Whittington, J., Juswono, U., Newman, I., and Shabala, S. (2001). Oscillations in proton transport revealed from simultaneous measurements of net current and net proton fluxes from isolated root protoplasts: MIFE meets patch-clamp. Austr. J. Plant Physiol. 28, 591-606. doi: 10.1071/PP01030

Tyerman, S. D., and Skerrett, I. M. (1998). Root ion channels and salinity. Sci. Hortic. 78, 175-235. doi: 10.1016/S0304-4238(98)00194-0

Tyerman, S. D., Skerrett, M., Garrill, A., Findlay, G. P., and Leigh, R. A. (1997). Pathways for the permeation of $\mathrm{Na}^{+}$and $\mathrm{Cl}^{-}$into protoplasts derived from the cortex of wheat roots. J. Exp. Bot. 48, 459-480. doi: 10.1093/jxb/48.Special_Issue.459

Valencia-Cruz, G., Shabala, L., Delgado-Enciso, I., Shabala, S., Bonales-Alatorre, E., Pottosin, I. I., et al. (2009). Kbg and Kv1.3 channels mediate potassium efflux in the early phase of apoptosis in Jurkat T lymphocytes. Am. J. Physiol. Cell Physiol. 297, C1544-C1553. doi: 10.1152/ajpcell.00064.2009

Verbelen, J. P., De Cnodder, T., Le, J., Vissenberg, K., and Baluska, F. (2006). The root apex of arabidopsis thaliana consists of four distinct zones of growth activities: meristematic zone. Plant Signal. Behav. 1, 296-304. doi: 10.4161/psb.1.6.3511

Volkov, V., and Amtmann, A. (2006). Thellungiella halophila, a salt-tolerant relative of Arabidopsis thaliana, has specific root ion-channel features supporting $\mathrm{K}^{+} / \mathrm{Na}^{+}$homeostasis under salinity stress. Plant J. 48, 342-353. doi: 10.1111/j.1365-313X.2006.02876.x

Volkov, V., Boscari, A., Clément, M., Miller, A. J., Amtmann, A., and Fricke, W. (2009). Electrophysiological characterization of pathways for $\mathrm{K}^{+}$uptake into growing and non-growing leaf cells of barley. Plant Cell Environ. 32, 17781790. doi: 10.1111/j.1365-3040.2009.02034.x

Volkov, V., Hachez, C., Moshelion, M., Draye, X., Chaumont, F., and Fricke, W. (2007). Water permeability differs between growing and non-growing barley leaf tissues. J. Exp. Bot. 58, 377-390. doi: 10.1093/jxb/erl203

Volkov, V., Wang, B., Dominy, P. J., Fricke, W., and Amtmann, A. (2004). Thellungiella halophila, a salt-tolerant relative of Arabidopsis thaliana, possesses effective mechanisms to discriminate between potassium and sodium. Plant Cell Environ. 27, 1-14. doi: 10.1046/j.0016-8025.2003.01116.x

Vrbka, L., Vondrásek, J., Jagoda-Cwiklik, B., Vácha, R., and Jungwirth, P. (2006). Quantification and rationalization of the higher affinity of sodium over potassium to protein surfaces. Proc. Natl. Acad. Sci. U.S.A. 103, 15440-15444. doi: 10.1073/pnas.0606959103

Walker, D. J., Black, C. R., and Miller, A. J. (1998). The role of cytosolic potassium and $\mathrm{pH}$ in the growth of barley roots. Plant Physiol. 118, 957-964. doi: 10.1104/pp.118.3.957

Walker, D. J., Smith, S. J., and Miller, A. J. (1995). Simultaneous measurement of intracellular $\mathrm{pH}$ and $\mathrm{K}^{+}$or $\mathrm{NO}_{3}$ - in barley root cells using triple-barreled, ion-selective microelectrodes. Plant Physiol. 108, 743-751.

Wang, B. (2006) Physiological and Molecular Strategies for Salt Tolerance in Thellungiella halophila, a Close Relative of Arabidopsis thaliana. Ph.D. thesis, Division of Biochemistry and Molecular Biology, Institute of Biomedical and Life Sciences, University of Glasgow, Glasgow, 235.

Wang, B., Davenport, R. J., Volkov, V., and Amtmann, A. (2006). Low unidirectional sodium influx into root cells restricts net sodium accumulation in Thellungiella halophila, a salt-tolerant relative of Arabidopsis thaliana. J. Exp. Bot. 57, 1161-1170. doi: 10.1093/jxb/erj116

Waters, S., Gilliham, M., and Hrmova, M. (2013). Plant high-affinity potassium (HKT) transporters involved in salinity tolerance: structural insights to probe differences in ion selectivity. Int. J. Mol. Sci. 14, 7660-7680. doi: $10.3390 /$ ijms 14047660

Wegner, L. H. (2013). Cation selectivity of the plasma membrane of tobacco protoplasts in the electroporated state. BBA Biomembr. 1828, 1973-1981. doi: 10.1016/j.bbamem.2013.04.010

Wegner, L. H. (2014). The conductance of cellular membranes at supra-physiological voltages. Bioelectricity 103, 34-38. doi: 10.1016/j. bioelechem.2014.08.005

Wegner, L. H., Flickinger, B., Eing, C., Berghöfer, T., Hohenberger, P., Frey, W. et al. (2011). A patch clamp study on the electro-permeabilization of higher plant cells: supra-physiological voltages induce a high-conductance. $B B A$ Biomembr. 1808, 1728-1736. doi: 10.1016/j.bbamem.2011.01.016

Wegner, L. H., Frey, W., and Schönwälder, S. (2013). A critical evaluation of whole cell patch clamp studies on electroporation using the voltage sensitive dye ANNINE-6. Bioelectrochemistry 92, 42-46. doi: 10.1016/j.bioelechem.2013.03.002

White, P. J. (1993). Characterization of a high-conductance, voltage-dependent cation channel from the plasma membrane of rye roots in planar lipid bilayers. Planta 191, 541-551. doi: 10.1007/BF00195756

White, P. J., Cooper, H. D., Clarkson, D. T., Earnshaw, M. J., and Loughman, B. C. (1991). Effects of low temperature on growth and nutrient accumulation in rye (Secale cereale) and wheat (Triticum aestivum). Ann. Bot. 68, 23-31.

White, P. J., and Lemtiri-Chlieh, F. (1995). Potassium currents across the plasma membrane of protoplasts derived from rye roots: a patch clamp study. J. Exp. Bot. 46, 497-511. doi: 10.1093/jxb/46.5.497

Winter, H., Robinson, D. G., and Heldt, H. W. (1994). Subcellular volumes and metabolite concentrations in spinach leaves. Planta 193, 530-535. doi: 10.1007/BF02411558

Wu, S. J., Ding, L., and Zhu, J. K. (1996). SOS1, a genetic locus essential for salt tolerance and potassium acquisition. Plant Cell 8, 617-627. doi: 10.1105/tpc.8.4.617

Wyn Jones, R. G. A., and Pollard, A. (1983). "Proteins, enzymes and inorganic ions," in Encyclopedia of Plant Physiology, New Series, Vol. 15B, eds A. Lauchli and A. Person (New York: Springer), 528-562.

Xue, S., Yao, X., Luo, W., Jha, D., Tester, M., Horie, T., et al. (2011). AtHKT1;1 mediates Nernstian sodium channel transport properties in Arabidopsis root stelar cells. PLoS ONE 6:e24725. doi: 10.1371/journal.pone.0024725

Yamaguchi, T., Aharon, G. S., Sottosanto, J. B., and Blumwald, E. (2005). Vacuolar $\mathrm{Na}^{+} / \mathrm{H}^{+}$antiporter cation selectivity is regulated by calmodulin from within 
the vacuole in a $\mathrm{Ca}^{2+}$ - and pH-dependent manner. Proc. Natl Acad. Sci. U.S.A. 102, 16107-16112. doi: 10.1073/pnas.0504437102

Yamaguchi, T., Apse, M. P., Shi, H., and Blumwald, E. (2003). Topological analysis of a plant vacuolar $\mathrm{Na}^{+} / \mathrm{H}^{+}$antiporter reveals a luminal C terminus that regulates antiporter cation selectivity. Proc. Natl. Acad. Sci. U.S.A. 100, 1251012515. doi: 10.1073/pnas.2034966100

Yamaguchi, T., Hamamoto, S., and Uozumi, N. (2013). Sodium transport system in plant cells. Front. Plant Sci. 4:410. doi: 10.3389/fpls.2013.00410

Yang, Q., Chen, Z. Z., Zhou, X. F., Yin, H. B., Li, X., Xin, X. F., et al. (2009). Overexpression of SOS (Salt Overly Sensitive) genes increases salt tolerance in transgenic Arabidopsis. Mol. Plant 2, 22-31. doi: 10.1093/mp/ssn058. doi: $10.1093 / \mathrm{mp} / \mathrm{ssn} 058$

Yue, Y., Zhang, M., Zhang, J., Duan, L., and Li, Z. (2012). SOS1 gene overexpression increased salt tolerance in transgenic tobacco by maintaining a higher $\mathrm{K}^{+} / \mathrm{Na}^{+}$ratio. J. Plant Physiol. 169, 255-261. doi: 10.1016/j.jplph.2011. 10.007

Zahran, H. H., Marín-Manzano, M. C., Sánchez-Raya, A. J., Bedmar, E. J., Venema, K., and Rodríguez-Rosales, M. P. (2007). Effect of salt stress on the expression of NHX-type ion transporters in Medicago intretexta and Melilotus indicus plants. Physiol. Plant. 131, 122-130. doi: 10.1111/j.13993054.2007.00940.x

Zdebik, A. A., Zifarelli, G., Bergsdorf, E. Y., Soliani, P., Scheel, O., Jentsch, T. J., et al. (2008). Determinants of anion-proton coupling in mammalian endosomal CLC proteins. J. Biol. Chem. 283, 4219-4227. doi: 10.1074/jbc.M708368200
Zhang, H. X., and Blumwald, E. (2001). Transgenic salt-tolerant tomato plants accumulate salt in foliage but not in fruit. Nat. Biotechnol. 19, 765-768. doi: $10.1038 / 90824$

Zhao, F. Y., Zhang, X. J., Li, P. H., Zhao, Y. X., and Zhang, H. (2006). Co-expression of the Suaeda salsa SsNHX1 and Arabidopsis AVP1 confer greater salt tolerance to transgenic rice than the single SsNHX1. Mol. Breed. 17, 341-353. doi: 10.1007/s11032-006-9005-6

Zhao, K. F., Fan, H., Song, J., Sun, M. X., Wang, B. Z., Zhang, S. Q., et al. (2005). Two $\mathrm{Na}^{+}$and $\mathrm{Cl}^{-}$Hyperaccumulators of the Chenopodiaceae. J. Integr. Plant Biol. 47, 311-318. doi: 10.1111/j.1744-7909.2005.00057.x

Zou, P., Zhao, Y., Douglass, A. D., Hochbaum, D. R., Brinks, D., Werley, C. A., et al. (2014). Bright and fast multicoloured voltage reporters via electrochromic FRET. Nat. Commun. 5, 4625. doi: 10.1038/ncomms5625

Conflict of Interest Statement: The author declares that the research was conducted in the absence of any commercial or financial relationships that could be construed as a potential conflict of interest.

Copyright $(9) 2015$ Volkov. This is an open-access article distributed under the terms of the Creative Commons Attribution License (CC BY). The use, distribution or reproduction in other forums is permitted, provided the original author(s) or licensor are credited and that the original publication in this journal is cited, in accordance with accepted academic practice. No use, distribution or reproduction is permitted which does not comply with these terms. 